\title{
Traditional agriculture: a climate-smart approach for sustainable food production
}

\author{
Rinku Singh $^{1}$ - G. S. Singh ${ }^{1}$ \\ ${ }^{1}$ Department of Environment and Sustainable Development, Institute of Environment and Sustainable Development, Banaras Hindu University, \\ Varanasi 221005, India
}

Received: 9 July 2016/Revised: 11 August 2017/Accepted: 12 August 2017/Published online: 4 September 2017

(C) Joint Center on Global Change and Earth System Science of the University of Maryland and Beijing Normal University and Springer-Verlag GmbH Germany 2017

\begin{abstract}
Sustainable food production is one of the major challenges of the twenty-first century in the era of global environmental problems such as climate change, increasing population and natural resource degradation including soil degradation and biodiversity loss. Climate change is among the greatest threats to agricultural systems. Green Revolution though multiplied agricultural production several folds but at the huge environmental cost including climate change. It jeopardized the ecological integrity of agroecosystems by intensive use of fossil fuels, natural resources, agrochemicals and machinery. Moreover, it threatened the age-old traditional agricultural practices. Agriculture is one of the largest sectors that sustain livelihood to maximum number of people and contribute to climate change. Therefore, a climate-smart approach to sustainable food production is the need of hour. Traditional agriculture is getting increased attention worldwide in context of sustainable food production in changing climate. The present article advocates traditional agriculture as a climate-smart approach for the sustainable food production and also deliberates the correlation between climate change and agriculture.
\end{abstract}

Keywords Agroforestry - Climate change - Climatesmart agriculture - Intercropping - Sustainability · Traditional agriculture

G. S. Singh

gopalsingh.bhu@gmail.com

\section{Introduction}

Climate change is one of the most debated issues of the twenty-first century in the socio-ecological and economic perspectives. Anthropogenic activities are largely responsible for mounting environmental problems such as climate change, environmental pollution and natural resource degradation including soil degradation and biodiversity loss. Human-induced changes are major drivers for current and projected climate change (Solomon 2007; Ramanathan and $\mathrm{Xu}$ 2010). Now climate change is a reality and the evidences can be traced through the global warming, glacier melting, sea level rising, ocean acidification, precipitation variability and extreme weather events (Adger et al. 2005; Solomon 2007). Average global temperature is expected to increase through $0.5-8.6^{\circ} \mathrm{F}$ by the end of the twenty-first century (IPCC 2013). This increased temperature would affect agricultural production significantly. Agriculture is among the highly sensitive systems influenced by change in weather and climate. In recent years, climate change impacts have been become the greatest threats to global food security (Tripathi et al. 2016; Islam and Nursey-Bray 2017). Climate change results a decline in food production and consequently rising food prices (IASC 2010; Bandara and Cai 2014). Climate change threats are further intensified by growing population. It is projected that global population will touch the historic mark of 9.5 billion by 2050 (Godfrey et al. 2010). To feed this large population, twofold of food production from the present level will be required (FAO 2016). Climate change impacts are more severe in the developing countries due to their agriculture based economy, warmer climate, frequent exposure to extreme weather events and 
lack of money for adaptation methods (Parry et al. 2001; Tubiello and Fischer 2007; Morton 2007; Touch et al. 2016).

According to Rockström et al. (2009), the boundaries in three systems viz., rate of biodiversity loss, human interference with the nitrogen cycle and climate change have already been overstepped. We are living in the anthropocene era where human-driven environmental changes deteriorate geographical and ecological resilience of the earth system (Crutzen 2002; Steffen et al. 2007; Rockstrom et al. 2009). Agriculture and climate change are correlated as both affect each other significantly (Paustian et al. 1997). It is estimated that contribution of agriculture, forestry and other land use (AFOLU) is about $21 \%$ in the total global emission of greenhouse gases (GHGs) (FAO 2016). Green Revolution though boosted agriculture production but at the huge socio-ecological cost such as environmental pollution, biodiversity loss, climate change, land degradation, erosion of traditional agricultural knowledge and decline in human health and livelihood (Redclift 1989; Alteri 2000; Eakin et al. 2007; Phungpracha et al. 2016; Srivastava et al. 2016). Excessive and inappropriate use of agrochemicals, fossil fuels, natural resources, machinery and adoption of high yielding varieties (HYVs) and monocropping patterns are the major causes for such socioecological cost (Phungpracha et al. 2016).

Climate change mitigation and adaptation are two foremost needs to reduce global warming impacts (Kongsager et al. 2016; Song and Ye 2017). Achieving the goals of eradicating hunger and poverty by 2030 while addressing the climate change impacts need a climate-smart approach in agriculture. Climate-smart agriculture (CSA) is based on the objectives of sustainably enhancing food production, climate adaptation and resilience and reduction in GHGs emission (FAO 2010). Traditional agricultural practices have regained the increased attention worldwide as climate-smart approach. Traditional agriculture is the outcome of experiences provided by local farming practices through thousands of years (Pulido and Bocco 2003). High productivity, biodiversity conservation, low energy inputs and climate change mitigation are some of the salient features of the traditional agriculture systems (Srivastava et al. 2016). Traditional agroecosystems are recognized as the time tested models of modern sustainable agriculture systems that occur today (Ellis and Wang 1997). Traditional practices like agroforestry, intercropping, crop rotation, cover cropping, traditional organic composting and integrated crop-animal farming have potentials for enhancing crop productivity and mitigating climate change. Indigenous farmers and local people perceive climate change in their own ways and prepare for it through various adaptation practices (Tripathi and Singh 2013).
Farmers due to dogged work and low profit shifted from traditional agriculture towards the modern one. Modern agriculture, however, enhanced food productivity but with the acceleration of several environmental problems such as climate change, food unsafety, biodiversity loss, soil degradation and environmental pollution (Zhang et al. 2017a). Modern agriculture is a major driver for the loss of crop genetic resources in the Third World due to adoption of HYVs and planting the vast fields with genetically uniform cultivars (Altieri and Merrick 1987). Traditional agricultural practices are usually restricted to small farmers. Traditional vegetables grow well in drought-prone areas. Traditional vegetable knowledge is under serious threat due to habitat loss, introduction of new varieties, historical policies, stigma attached to the use of traditional vegetables and altered lifestyle (Dweba and Mearns 2011). In the context of sustainable food production in changing climate, adoption of climate-smart traditional practices is an urgent need. It is right time to rediscover and reimplement traditional practices to improve the socio-ecological integrity of agroecosystems. Integration of traditional agriculture with modern agriculture is the necessity of current scenario. This integration would bridge the huge gap between indigenous and modern peasants. Moreover, it would fortify the human-nature relationships. The aim of this article is to advocate traditional agriculture as a climate-smart approach for sustainable food production. Moreover, agriculture-climate change correlation is also described at substantial level. Authors also stated some recommendations for sustainable food production in changing climate.

\section{Agriculture and climate change: a two-way relationship}

Climate change is statistically significant difference in either the mean state of the climate or in its variability, continuing for a long period usually decades or longer (VijayaVenkataRaman et al. 2012). It refers to both a shift in mean climatic conditions (e.g. temperature and precipitation) and an increase in the frequency and severity of weather extremes (Tebaldi et al. 2006; Eitzinger et al. 2013; Porter et al. 2014; Mandryk et al. 2017). Economic activities prompted by industrial revolution have been contributed to climate change through increasing GHGs emission (IPCC 2007a). Agricultural activities from cropping to harvesting emit GHGs that cause climate change which in turn disturbs agriculture (Paustian et al. 1997). Therefore, climate change and agriculture are correlated (Fig. 1).

Agriculture is one of the major contributors of global warming through a share of about $10-12 \%$ increase in total 


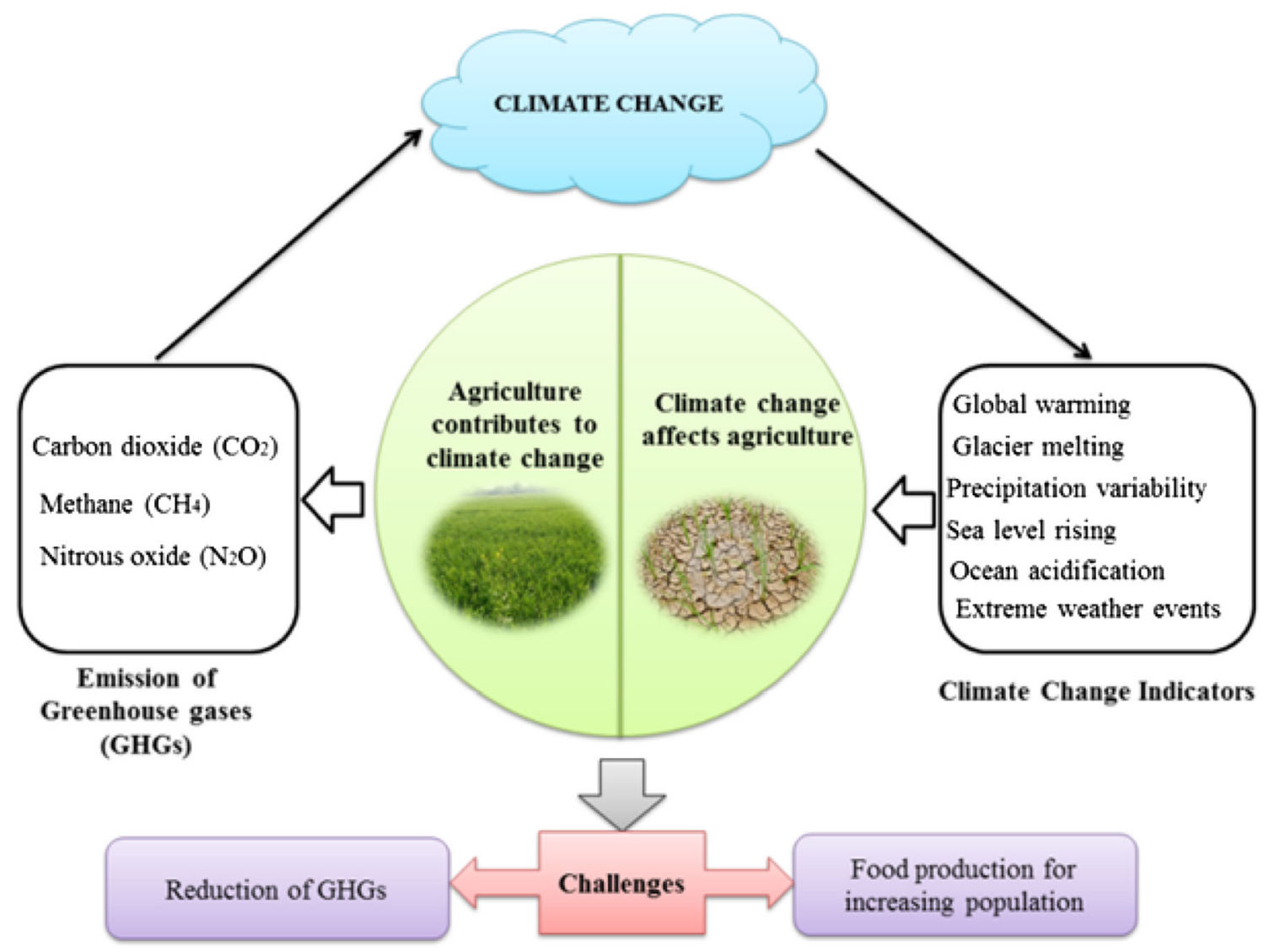

Fig. 1 Correlation between agriculture and climate change

anthropogenic GHG emission (Stocker et al. 2013). Carbon dioxide $\left(\mathrm{CO}_{2}\right)$, methane $\left(\mathrm{CH}_{4}\right)$ and nitrous oxide $\left(\mathrm{N}_{2} \mathrm{O}\right)$ are major GHGs emitted by agricultural activities (Tellez-Rio et al. 2017). In year 2005, it was estimated that globally agriculture accounted to 50 and $60 \%$ of total anthropogenic $\mathrm{CH}_{4}$ and $\mathrm{N}_{2} \mathrm{O}$ emissions, respectively (Liu et al. 2015). Agroecosystems are highly sensitive and vulnerable to climate change (Parry and Carter 1989; Reilly 1995; IPCC 2014). Climate change is a severe threat to both food production and human health (McMichael et al. 2007). It influences agriculture through increased temperature, precipitation variability and amplified intensity of weather extremes. Climate change affects agriculture directly through altering the agroecological conditions and indirectly by increasing demand of agricultural production (Schmidhuber and Tubiello 2007). Climate change is a serious threat to all aspects of agriculture including production, distribution, food accessibility and food prices (Tai et al. 2014; Islam and Nursey-Bray 2017). During 1980 to 2008 , there was a $5.5 \%$ fall in wheat yields and a $3.8 \%$ fall in maize yields globally, compared to their yields in stable climate (Lobell et al. 2011). Climate change also affects the invasive crop pest species (Yan et al. 2017), livestock production (Rojas-Downing et al. 2017) and aquaculture (Porter et al. 2014). Tropical and developing countries are at the greater risk to climate change as compared to temperate and developed countries and this scenario encounters current and future food production (Gornall et al. 2010; Hillel and Rosenzweig 2010; Deryng et al. 2014; Porter et al. 2014; Challinor et al. 2014).

\section{Climate-smart agriculture: principles and objectives}

Food and Agriculture Organization (FAO) devised the climate-smart agriculture (CSA) approach in order to manage agriculture for food security in the era of global warming (FAO 2010). The CSA approach has three objectives: (1) sustainably enhancing agricultural productivity to support equitable increase in income, food security and development (2) increasing adaptive capacity and resilience to shocks at multiple levels, from farm to national and (3) reducing GHG emissions and increasing carbon sequestration where possible. Sustainable food production while reducing $\mathrm{GHG}$ emissions and increasing climate resilience of agricultural system is the foremost objective of CSA (Harvey et al. 2014; Brandt et al. 2015). 
Lipper et al. (2014) defined CSA as the strategy that transforms and reorients agroecosystems to produce food in climate change scenario. According to Olayide et al. (2016), CSA is an emerging approach to enhance food production, biodiversity, environmental quality, agroecosystem resilience, livelihoods and economic development while addressing the climate change impacts. Relative priority of each of the objective of CSA fluctuates with locations, for example, small farmers of developing countries need more emphasis on productivity and adaptive capacity (Neufeldt et al. 2013; Campbell et al. 2014). CSA has been getting a mounting attention particularly in developing world due to its capabilities to enhance agricultural productivity and agroecosystem resilience while reducing GHG emission (Grainger-Jones 2011; Long et al. 2016; Mwongera et al. 2017).

\section{Traditional agriculture: concept and agroecological features}

Traditional knowledge is holistic in nature due to its multitude applications in diverse fields such as agriculture, climate, soils, hydrology, plants, animals, forests and human health (Howes and Chambers 1980; Jungerius 1985; Wilken 1987; Agrawal 1995; Pulido and Bocco 2003). Husbandry and agriculture are among the oldest practices through which human have been interacting with nature and managing ecosystem services (Fisher et al. 2009). Traditional agriculture is the result of the experiences delivered by the local farming practices through thousands of years (Pulido and Bocco 2003). Traditional farming practices contributed a significant role to the building of scientific knowledge in agriculture (Sandor and Furbee 1996; Singh et al. 1997a). These have been nourished a sizeable population for centuries and continue to feed people in many regions of the world (Koohafkan and Altieri 2010).

Farmers throughout the world particularly in developing regions use local, traditional or landraces of both minor and major crops (Jackson et al. 2007). Although modern agriculture has been adopted by farmers in every corners of the globe, but 1.9-2.2 billion people still use traditional methods in agriculture (Altieri 1993; Pretty 1995). Small farmers are stewards of the traditional agricultural practices, and globally about $84 \%$ of farms have area less than 2 ha that operate $12 \%$ of farmland (Altieri 2004; Lowder et al. 2016). Smallholder farmers adjust to environmental changes through their indigenous knowledge and experience such as changing farming practices and cultivating adapted crops (Lasco et al. 2014). China ranks first in terms of total small farms followed by India, Indonesia, Bangladesh and Vietnam (Altieri 2009). In Sub Saharan Africa, smallholder farmers comprise $80 \%$ of all farms and their traditionally cultivated fields are generally more productive than that of large-scale farmers (Stifel 1989; Bridge 1996; Kuivanen et al. 2016). About $70 \%$ of Mexician peasants particularly smallholders cultivate their fields with traditional agriculture practices (Aguilar-Jiménez et al. 2013). Farmers in traditional agroecosystems of the Himalayan mountains are largely dependent on the locally available resources and indigenous technology (Nautiyal et al. 2007).

Traditional agricultural landscapes refer to the landscapes with preserved traditional sustainable agricultural practices and conserved biodiversity (Harrop 2007; Lieskovský et al. 2015). They are appreciated for their aesthetic, natural, cultural, historical and socio-economic values (Barankova et al. 2011; Lieskovský et al. 2015). Traditional farming landscape occurs in regions where farming practices either remain same or change comparatively little over a long period of time (Fischer et al. 2012). Some prominent examples of these regions include the Western Ghats of India, the Satoyama landscapes in Japan, the Milpa cultivation systems in Mexico, traditional village systems in Eastern Europe and South-western China's terrace landscapes (McNeely and Schroth 2006; Palang et al. 2006; Ranganathan et al. 2008; Hartel et al. 2010; Takeuchi 2010; Robson and Berkes 2011; Fischer et al. 2012; Liu et al. 2012). The Hani rice terraces of Yunnan Province in Southwest of China are one of the well-known agricultural systems in mountainous regions. These terraces have been designated as Globally Important Agricultural Heritage Systems (GIAHS) in 2009 by FAO and World Cultural Heritage (WCH) sites by United Nations Educational, Scientific and Cultural Organization (UNESCO) in 2013 (Zhang et al. 2017b).

During the last few decades, agrobiodiversity has reduced due to intensive monoculture farming (Matson et al. 1997; Evenson and Gollen 2003; Sardaro et al. 2016). About $80 \%$ of the world's arable land is planted with a handful of crops such as corn, wheat, rice, soyabean and others (Adams et al. 1971; Heinemann et al. 2013; Altieri et al. 2015). FAO estimated that $75 \%$ of the world's food crop diversity has lost in the twentieth century due to replacement of local varieties by genetically uniform HYVs (FAO 2009; Gonzalez 2011). Worldwide traditional farmers are recognized as the custodians of natural resources including biodiversity (Chhatre and Agrawal 2008). Traditional farmers preserve genotypes through unique and valuable traits within their herds and traditional crop varieties that tolerate environmental stresses including climate change (Boyce 2006; Gonzalez 2010, 2011; Johns et al. 2013). High vegetational diversity and a multifaceted system of indigenous knowledge are the salient features of traditional farming systems in developing countries (Altieri 1993; Gliessman1998; Altieri 2002). Himalayan 
agroecosystems are rich in crop diversity and traditional agriculture (Maikhuri et al. 1996; Singh et al. 1997b; Kuniyal et al. 2004).

Post-hunter-gather societies have been progressively dependent on extra-somatic energy for food production (McMichael et al. 2007). Food production needs energy in every step from cropping to harvesting and harvesting to distribution. Synthetic nitrogen fertlizers are among the high energy demanding sides of modern agriculture (Pelletier et al. 2011). Local knowledge and locally available resources have been utilized by peasants to develop sustainable farming systems (Altieri et al. 1987). Integration of crop and livestock is a strategy that helps farmers to reduce their reliance on external inputs such as fossil fuels, fertlizers and pesticides (Schiere and Kater 2001; Naylor et al. 2005; Anex et al. 2007). Unlike the modern agriculture systems where the link between agroecosystem and consumer is uni-directional, traditional agriculture systems are linked by bi-directon through recycling of agriculture and other wastes (Ellis and Wang 1997). Agrobiodiversity supplies a range of ecosystem services to agriculture and reduce the need of off-farm inputs. Composting and manuring increase soil microbial and invertebrate communities which improve nutrient cycling (Mäder et al. 2002; Reganold et al. 2010; Kremen and Miles 2012). Indigenous farmers of Asia, Africa and Latin America through continuously farming in extreme weather events have developed farming systems resilient to environmental variability with minimal external inputs (Denevan 1995; Altieri et al. 2015).

\section{Traditional agriculture: alternative practices for climate change mitigation}

Climate change mitigation is a human-mediated reduction of the anthropogenic forcing of climate system that includes strategies to reduce GHG sources and emissions and enhancing GHG sinks (Halsnæs et al. 2007). Indigenous people are good observers of changes in weather and climate and acclimatize through several adaptive and mitigation strategies (Salick and Byg 2007; Macchi et al. 2008; Salick and Ross 2009). Traditional agroecosystems are receiving rising attention as sustainable alternatives to industrial farming (Fraser et al. 2015). They are getting increased considerations for biodiversity conservation and sustainable food production in changing climate (Selmi and Boulinier 2003). Indigenous agriculture systems are diverse, adaptable, nature friendly and productive (Fernandez 1994). Higher vegetational diversity in the form of crops and trees escalates the conversion of $\mathrm{CO}_{2}$ to organic form and consequently reducing global warming (Misra et al. 2008). Mixed cropping not only decreases the risk of crop failure, pest and disease but also diversifies the food supply (Sauerborn et al. 2000). It is estimated that traditional multiple cropping systems provide $15-20 \%$ of the world's food supply (Altieri 1999a). Agroforestry, intercropping, crop rotation, cover cropping, traditional organic composting and integrated crop-animal farming are prominent traditional agricultural practices. These traditional practices are advocated as the model practices for climate-smart approach in agriculture (Fig. 2; Table 1).

\subsection{Agroforestry}

Trees are well-known sink for carbon dioxide. They fix carbon through the process of photosynthesis and store excess carbon as biomass (Nowak and Crane 2002). The integration of trees with crops is an age-old practice that dates to the beginning of farming and animal husbandry (Oelbermann et al. 2004). Agroforestry is a practice of planting trees with crops to exploit the ecological and economic interactions of the different components (Lundgren 1982; Nair 1993; Young 1997; Albrecht and Kandji 2003). It is widely adopted as a climate-smart practice due to its potentials for climate change mitigation, adaptation, crop productivity and food security (Nair et al. 2009; Mbow et al. 2014; Luedeling et al. 2014; Coulibaly et al. 2017). Agroforestry enhances soil organic matter (SOM), agriculture productivity, carbon sequestration, water retention, agrobiodiversity and farmers' income (Nyong et al. 2007; Schoeneberger et al. 2012; Zomer et al. 2016; Paul et al. 2017). Carbon sequestration through agroforestry influenced by several factors such as type of agroecosystems, tree species, age of tree species, geographical location, environmental factors and management practices (Jose 2009). Tree components in crop fields reduce the severity of extreme weather events such as floods, hurricanes and tropical storms (Lin 2011; Matocha et al. 2012). Trees in fields serve as the windbreaks and shelter belts (Lasco et al. 2014).

Agroforestry is practised worldwide as a land-use management system but widespread in tropical regions (Pandey 2002). It is a common practice in Southeast Asia, Latin America and Equatorial Africa (Beer et al. 1990; Szott et al. 1991; Herzog 1994). About 1.2 billion people in developing countries depend on agroforestry to sustain their livelihood and agricultural productivity (FAO 2011b; Meijer et al. 2015). The cocoa agroforestry in West and Central Africa is a traditional method of integrating forest component with crops. It is a multistrata agroforestry that provides agroforestry tree products (AFTPs) like highquality timber and fruits (Simons and Leakey 2004). Dhesa system of Spain is a traditional agroforestry system with animal components. In this system, area under forest canopy is cleared by grazing to use it as cropland (Linares 


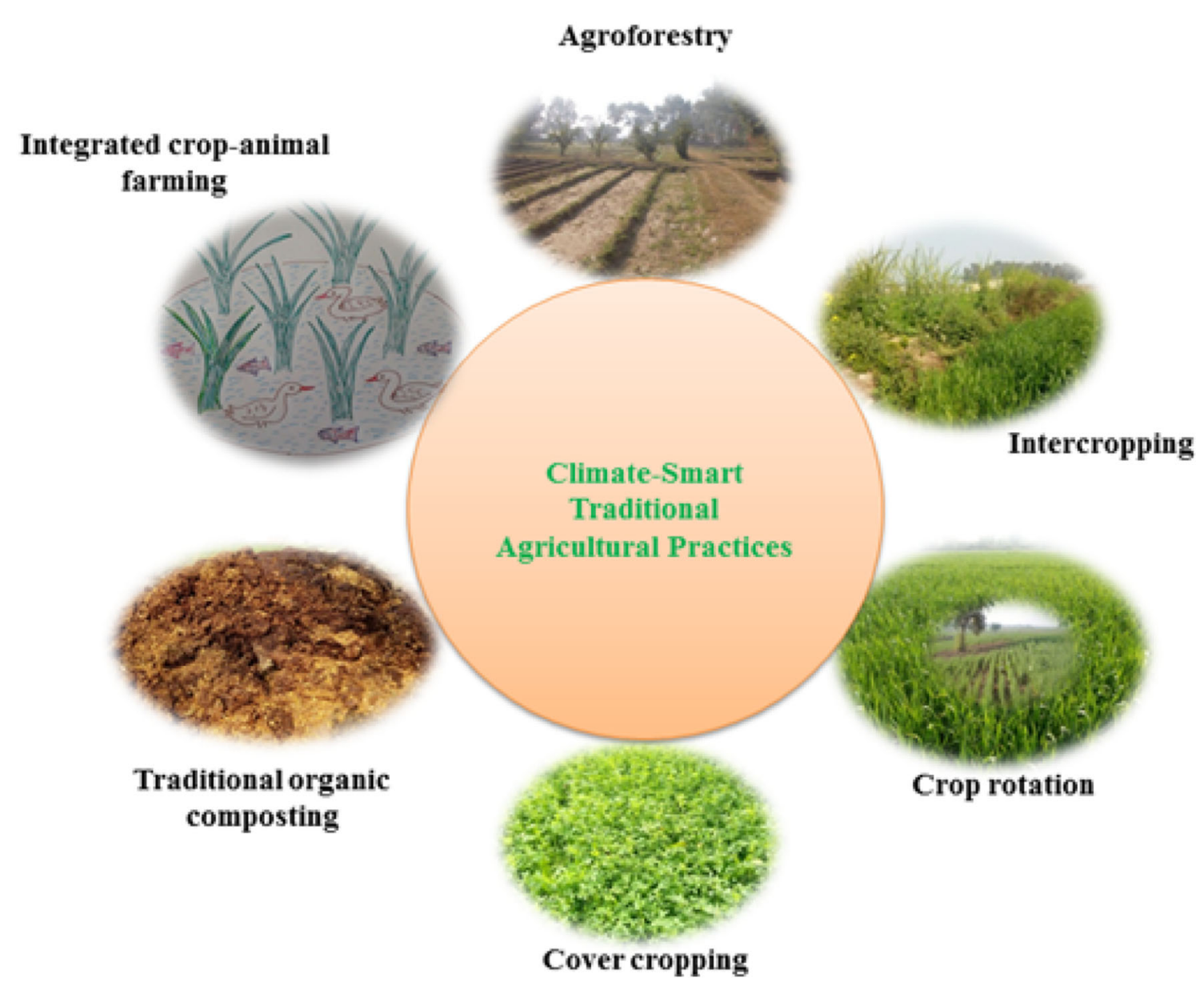

Fig. 2 Climate-smart traditional agricultural practices

2007). Integration of animals into farming systems not only provide milk and meat but also recycle their feed into manure that enhances the carbon sequestration (Altieri 1999b). Agroforestry systems are highly adapted to drought conditions as deep roots of tree explore a larger soil volume for water and nutrients (Verchot et al. 2007). In the current scenario of rising prices of fossil fuels, agrochemicals, food shortages and changing climate, agroforestry has been increasingly adopted as a cost-effective and climate-smart approach for food production (Mbow et al. 2014).

\subsection{Intercropping}

Intercropping, the concurrent cultivation of more than one crop species on the same field is a practical application of basic ecological principles such as diversity, competition and facilitation (Hauggaard-Nielsen et al. 2008). It is one of the highly productive farming systems (Hu et al. 2017). Intercropping reduces the climate-driven crop failure as variety of crops have different climatic adaptability (Shava et al. 2009). Intercrops efficiently utilize the natural resources such as land, light, water and nutrient and increase biodiversity, productivity, resilience and stability of agroecosystem (Zhang and Li 2003; Mushagalusa et al. 2008; Ning et al. 2017). Analysis of long-term experiments indicated that increasing crop rotation intensity from single crop (corn) to double crop (corn-soybean) enhanced carbon sequestration by $20 \mathrm{~g} \mathrm{~cm}^{-2}$ year $^{-1}$ in humid continental climate at Wooster of Ohio, USA (West and Post 2002). In India, intercropping is an ancient agricultural practice, particularly intercropping of sorghum and pigeon pea (Willy 1983; Wang et al. 2010). Latin American farmers grow their $70-90 \%$ of the beans with maize, potatoes and other crops (Francis 1986). Wheat-maize intercropping combined with conservation agricultural practices can be used for reducing $\mathrm{CO}_{2}$ emission and increasing crop productivity (Hu et al. 2017). Rubber-sugarcane intercropping is a sustainable and environmental friendly method to produce economic benefits while enhancing carbon sequestration (Kumara et al. 2016).

Intercropping of legumes with cereals optimizes the facilitation under nutrient limited conditions (Mao et al. 2015). Legumes make a symbiotic association with 
Table 1 Examples of climate-smart traditional agricultural practices and their role in climate change mitigation

\begin{tabular}{|c|c|c|c|c|c|}
\hline \multicolumn{4}{|c|}{ Climate-smart traditional agricultural practices } & \multicolumn{2}{|c|}{$\begin{array}{l}\text { Role of traditional agricultural practices in climate change } \\
\text { mitigation }\end{array}$} \\
\hline $\begin{array}{l}\text { Traditional } \\
\text { practices }\end{array}$ & Location & Brief description & Reference & Climate change mitigation & Reference \\
\hline Agroforestry & $\begin{array}{l}\text { West and } \\
\text { Central } \\
\text { Africa }\end{array}$ & $\begin{array}{l}\text { Traditional cocoa agroforestry to } \\
\text { sustainably utilize land and } \\
\text { natural resources }\end{array}$ & $\begin{array}{l}\text { Simons } \\
\text { and } \\
\text { Leakey } \\
(2004)\end{array}$ & $\begin{array}{l}\text { Agroforestry systems mitigate nitrous } \\
\text { oxide }\left(\mathrm{N}_{2} \mathrm{O}\right) \text { and methane }\left(\mathrm{CH}_{4}\right) \\
\text { emission } \\
\text { Agroforestry mitigates climate change } \\
\text { through enhancing the carbon } \\
\text { sequestration }\end{array}$ & Mutuo et al. (2005) \\
\hline Intercropping & $\begin{array}{l}\text { Latin } \\
\text { America }\end{array}$ & $\begin{array}{l}\text { Intercropping of beans with maize, } \\
\text { potatoes and other crops }\end{array}$ & $\begin{array}{l}\text { Francis } \\
(1986)\end{array}$ & $\begin{array}{l}\text { Intercropping enhances carbon } \\
\text { sequestration }\end{array}$ & $\begin{array}{l}\text { West and Post } \\
\text { (2002) }\end{array}$ \\
\hline Crop rotation & $\begin{array}{l}\text { Southern } \\
\text { Spain }\end{array}$ & $\begin{array}{l}\text { Rotation between drum wheat and } \\
\text { sunflower }\end{array}$ & $\begin{array}{l}\text { Pedraza } \\
\text { et al. } \\
(2015)\end{array}$ & $\begin{array}{l}\text { Leguminous crops in rotation increase } \\
\text { soil's potential to sequester carbon and } \\
\text { add nitrogen into soil }\end{array}$ & Lal (2011) \\
\hline $\begin{array}{l}\text { Cover } \\
\text { cropping }\end{array}$ & Paraguay & $\begin{array}{l}\text { Growing grey-seeded mucuna } \\
\text { leaves as cover crops }\end{array}$ & $\begin{array}{l}\text { FAO } \\
\quad(2011 a)\end{array}$ & $\begin{array}{l}\text { Cover crops enhance soil organic carbon } \\
\text { (SOC) pool }\end{array}$ & Lal (2004) \\
\hline $\begin{array}{l}\text { Traditional } \\
\text { organic } \\
\text { composting }\end{array}$ & India & $\begin{array}{l}\text { Use of composted farmyard } \\
\text { manure (FYM) is a common } \\
\text { practice in Indian Himalayan } \\
\text { villages }\end{array}$ & $\begin{array}{l}\text { Gopinath } \\
\text { et al. } \\
\text { (2008) }\end{array}$ & $\begin{array}{l}\text { Organic compost enhances the soil } \\
\text { organic matter (SOM) that improves } \\
\text { carbon sequestration }\end{array}$ & $\begin{array}{l}\text { Drinkwater et al. } \\
\text { (1998), Johnston } \\
\text { (1994), Tilman } \\
\text { (1998) }\end{array}$ \\
\hline \multirow{2}{*}{$\begin{array}{l}\text { Integrated } \\
\text { crop- } \\
\text { animal } \\
\text { farming }\end{array}$} & \multirow[t]{2}{*}{ China } & \multirow[t]{2}{*}{ Duck-rice-fish culture system } & \multirow[t]{2}{*}{$\begin{array}{l}\text { Juanwen } \\
\text { et al. } \\
\text { (2012) }\end{array}$} & $\begin{array}{l}\text { Diversified livelihood and optimum } \\
\text { utilization of natural resources in } \\
\text { changing climate }\end{array}$ & Howden et al. (2007) \\
\hline & & & & $\begin{array}{l}\text { Duck-rice culture reduces the external } \\
\text { input of nitrogen fertilisers and } \\
\text { consequently lowering of } \mathrm{N}_{2} \mathrm{O} \\
\text { emission }\end{array}$ & Long et al. (2013) \\
\hline
\end{tabular}

rhizobium bacteria that help in nitrogen fixation (Duchene et al. 2017). Leguminous crops not only reduce the $\mathrm{N}_{2} \mathrm{O}$ emission from agricultural fields but also enhance the release and turnover of mineralizable N-containing compounds in soil (Rochette and Janzen 2005; Jensen et al. 2010; Scalise et al. 2017). Global warming potential of $\mathrm{N}_{2} \mathrm{O}$ is 298-fold higher than $\mathrm{CO}_{2}$ and agriculture alone contributes to about $60 \%$ to the total anthropogenic $\mathrm{N}_{2} \mathrm{O}$ emission (Syakila and Kroeze 2011; Hauggaard-Nielsen et al. 2016). Intensive application of nitrogen fertilisers has been altered climate system and the global $\mathrm{N}$ cycle through emissions of $\mathrm{N}_{2} \mathrm{O}$ (Bouwman et al. 2002; Rashti et al. 2015). Legume intercropping help in reducing the external input of nitrogen fertilisers. Intercropped legumes enhance the availability of nutrients (nitrogen and phosphorus), crop growth and nutrient use efficiency (Latati et al. 2013; Lazali et al. 2016; Latati et al. 2017). Intercropping of maize with legumes reduces nitrate leaching and synthetic fertilisers input and enhances agrobiodiversity, soil health and crop yield (von Cossel et al. 2017). Green manure in the form of legume intercrops reduces soil erosion through enhancing soil aggregate stability (Gomes et al. 2009; Forte et al. 2017). They also encourage N-retention in soil (Cherr et al. 2006; Gabriel and Quemada 2011; Forte et al. 2017).

\subsection{Crop rotation}

Crop rotation refers to the practice of growing a sequence of plant species on the same land (Bullock 1992; Dury et al. 2012). It is an ancient practice that has been used for thousands of years (Bullock 1992; Hobbs et al. 2008). Crop rotation has been recaptured the global attention to solve the increasing agroecological problems such as declining soil quality and climate change resulting from short rotation and monocropping (Liu et al. 2016). Crop rotation is an effective approach for carbon sequestration as compared to growing same type of crop continuously (Triberti et al. 2016). It is a potential practice to reduce the emissions of $\mathrm{CH}_{4}$ and other GHGs in irrigated-rice fields (Theisen et al. 2017). According to Cha-un et al. (2017), when rice was cultivated in rotation with corn and sweet sorghum in dry season, there was a significant reduction in $\mathrm{GHG}$ emission (combined $\mathrm{CH}_{4}$ and $\mathrm{NO}_{2}$ in $\mathrm{CO}_{2}$ equivalent) by $68-78 \%$ as compared to double rice cultivation. Crop rotation is a sustainable approach that increases yield and water use efficiency while reducing soil erosion (Huang et al. 2003). In rain fed areas of Southern Spain, rotation between drum wheat (Triticum drum) and sunflower (Helianthus annuus) is a traditional practice that increases soil fertility (Pedraza 
et al. 2015). Crop rotation enhances the soil quality and crop productivity through altering soil structure and aggregation, SOC concentration, nutrient cycling and pests and diseases (Jarecki and Lal 2003).

The selection of a crop for incorporating it in rotations is very important. In crop rotation practice, species that enhance $\mathrm{N}$ in the soil can increase the phytomass production of the subsequent crops and consequently increasing SOM (Peoples and Baldock 2001; Raphael et al. 2016). Increasing SOM is a sustainable method to enhance crop productivity while increasing carbon sequestration and maintaining global C-cycle. Soil store more organic carbon than that of the atmosphere and global vegetation combined (Lehmann and Kleber 2015). Leguminous crops reduce reliance on $\mathrm{N}$-fertilisers like NPK that emits $\mathrm{N}_{2} \mathrm{O}$ and thereby reducing fossil fuel consumption in manufacturing of fertlizers and consequently lowering of $\mathrm{CO}_{2}$ emission (Zentner et al. 2001, 2004; Wang et al. 2010). Further, such crops improve the soil carbon sequestration (Lal 2011). It is estimated that corn-soybean rotation enhances crop productivity and amount of crop residues as compared to monoculture of corn or soybean (Wang et al. 2010). Cowpea (Vigna unguiculata) is an important legume for both human food and livestock fodder. It is a droughttolerant traditional crop that is well grown in semi-arid tropics Asia, Africa, Central and South America (Singh et al. 2003). Cow pea is an efficient nitrogen fixer that grows well in sandy and nutrient poor soils (Sanginga et al. 2000; Singh et al. 2003).

\subsection{Cover cropping}

Cover cropping is a sustainable approach for enhancing soil health, soil microbial biomass and agroecosytem services such as nutrient cycling, water storage, weed and pest control and carbon sequestration (Schipanski et al. 2014; Frasier et al. 2016; Pinto et al. 2017). Cover crop refers to the crop that is grown to cover the ground for reducing soil erosion and nutrient loss (Reeves 1994; Dabney et al. 2001). They are usually non-cash crops sown in the autumn to provide winter ground cover (Cooper et al. 2017). Replacement of a bare fallow period through cover cropping is a sustainable strategy for reducing runoff and soil erosion (Reeves 1994; Alvarez et al. 2017). Cover crops can be harvested before planting of the main crops or they can be grown alongside the main crop to provide living mulch (Robacer et al. 2016). Cover crops can be leguminous (e.g. pea, vetch and clover) or non-leguminous (e.g. rye, sorghum and brassicas) (Cooper et al. 2017). Rye, oat, pea, vetch, clover, sun hemp, velvet bean and sorghum are among the prominent cover crop species that are grown to enhance soil fertility and soil carbon sequestration (Wang et al. 2010). Sorghum is a drought-tolerant cover crop
(Montgomery et al. 2016). In Paraguay, cover cropping is a traditional practice. In Paraguay, indigenous people grow grey-seeded mucuna leaves which are excellent dead cover that protects soil from erosion and weeds (FAO 2011a). Cover crops are sustainable farming tool that increase SOM and improve soil water dynamics (Steele et al. 2012; Poeplau and Don 2015; Basche et al. 2016; Duval et al. 2016). Basche et al. (2016) found that long-term use of a winter rye cover crop enhanced soil water dynamics such as water content and soil water storage in a maize-soybean cropping system.

Cover crops are recognized as the green manure. They add nitrogen to the agroecosystem either by fixation or by improving the $\mathrm{N}$-mineralization, consequently declining synthetic fertilisers inputs and their resultant GHG emissions (Dabney et al. 2001; Thorup-Kristensen et al. 2003; Fageria et al. 2005; Schipanski et al. 2014; Li et al. 2015; Alvarez et al. 2017). Legume cover crops provide sufficient nitrogen to crops grown in rotation and consequently reducing external inputs of the synthetic fertilisers (Magdoff and Weil 2004; Gselman and Kramberger 2008; Robacer et al. 2016). Grass and legume winter cover crops are recognized as the sustainable tool to supporting nutrient cycling and conserving water and soil resources (Ranells and Wagger 1996; Jahanzada et al. 2017). Legume cover cropping is commonly practised by smallholder farmers in tropics (Mendham et al. 2004). Legume cover crops enhance SOM, biodiversity and carbon sequestration (Uhlen and Tveitnes 1995; Fullen and Auerswald 1998; Singh et al. 1998; Lal 2004). SOC maintenance or enrichment is a key provision for increasing soil ecosystem services including carbon sequestration (Hwang et al. 2017). Cover crops services in SOC pool enrichment has been reported from European countries such as Hungry, UK, Sweden, Netherlands (Johnston 1973; Van Dijk 1982; Nilsson 1986; Berzseny and Gyrffy 1997; Smith et al. 1997; Fullen and Auerswald 1998; Lal 2004). Velvet bean (Mucuna utilis) is a potential cover crop for the humid tropics of West Africa that improves SOC pool (Lal 2004). Sainju et al. (2016) reported that SOC increased by $0.4 \%$ with rye in momoculture and $3 \%$ with vetch and rye in biculture at $0.30 \mathrm{~cm}$.

\subsection{Traditional organic composting}

Fertiliser-driven GHG emission is the largest source of total GHG emission from agriculture sector (Wang et al. 2017). Inorganic nitrogen $(\mathrm{N})$ fertilisers contribute to approximately $75 \%$ of direct emission from agricultural soil (Zheng et al. 2004; Mohanty et al. 2017). Besides contributing to GHG emission, nitrogenous fertilisers decrease soil microbial activity and bacterial diversity (Ding et al. 2017). On the other hand, use of organic compost is a sustainable and climate-smart approach to 
increase soil fertility. The use of composted organic wastes to enhance soil fertility and productivity is gaining huge attention worldwide (Goyal et al. 2005). Composting is a traditional practice that has been used for centuries (Oudart et al. 2015). Composting refers to the natural process of rotting or decomposition of organic matter by microorganisms under controlled conditions (Misra et al. 2003). It is a biochemical process in which microbial degradation of organic waste results into a product known as organic manure or compost (Onwosi et al. 2017). Composting is a sustainable approach for organic waste management. It not only removes the waste but also transforms waste into nutrient-rich organic product that can be used to enhance soil fertility (Neher et al. 2013). Variety of organic materials are used in composting process such as straw, crop residues, agroindustry by-products, livestock waste, sewage sludge and kitchen waste (Proietti et al. 2016). A simplified model of traditional organic composting is presented in Fig. 3.

Organic composting process begins after putting the organic waste in a pit for several days or months. The heap of organic waste undergoes microbial degradation that converts organic waste into compost. During composting, organic material passes through the thermophilic phase $\left(45-65{ }^{\circ} \mathrm{C}\right)$ that kills numerous pathogenic microorganisms due to release of $\mathrm{CO}_{2}$, water and heat (Lung et al. 2001; Alidadi et al. 2005; Mehta et al. 2014; Soobhany et al. 2017). Several physio-chemical parameters affect the composting process such as temperature, moisture, $\mathrm{pH}$, particle size, aeration and electrical conductivity ( $\mathrm{Li}$ et al. 2013; Juárez et al. 2015; Onwosi et al. 2017). Organic compost increases soil carbon sequestration and reduces GHGs emission (Forte et al. 2017). It enriches SOM, soil fertility, soil microbial diversity, soil moisture, cation exchange capacity, soil aeration and reduces soil erosion and crop pests and diseases (Tester 1990; Diaz-Zorita et al. 1999; Peacock et al. 2001; Mäder et al. 2002; Magdoff and Weil 2004; Sun et al. 2004; Fließbach et al. 2007; Ge et al. 2008; Zhang et al. 2012; Liu et al. 2013). It is widely recognized that animal manure and crop straw enhance the SOM and crop yield (Yang et al. 2004).

It is estimated that global average sequestration potential of organic croplands is $0.9-2.4 \mathrm{Gt} \mathrm{CO}_{2}$ /year (Niggli et al. 2009). Organic matter not only makes soils more resistant to drought but also makes them adaptable with low and high rainfall (Lotter 2003; Bot and Benites 2005; Lal 2008). The use of organic manure can increase soil carbon or nitrogen levels in twofold in about 40 years

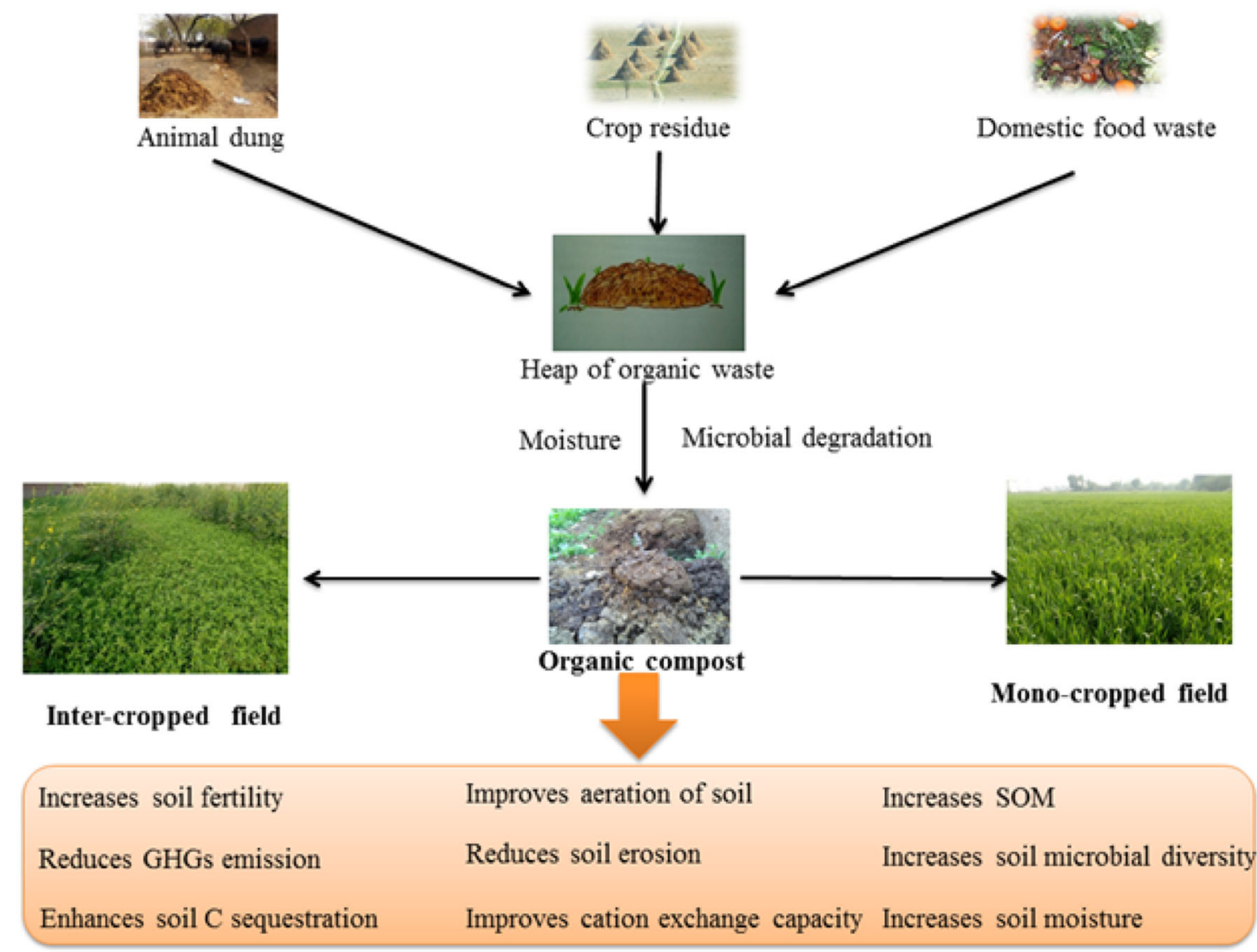

Fig. 3 A simplified model of traditional organic composting 
(Jenkinson et al. 1994; Powlson 1994; Tilman 1998). Traditional thermophillic composting is a low-energy, costefficient and sustainable approach to address the issues of soil fertility, environmental pollution, waste management and reducing chemical fertiliser inputs (Ndegwa and Thompson 2001; Nasiru et al. 2013; Soobhany et al. 2017). Composting is an important tool to social, ecological and economic sustainability (Scarpato and Simeone 2013; Proietti et al. 2016).

Application of organic resources for soil fertility is a common practice among the smallholder farmers in the tropics due to their inability to purchase costly mineral fertilisers (Palm et al. 2001). Compost preparation is prominent in Asian countries (Yadav et al. 2017). India has a long history of using organic manure to enhance soil fertility (Manna et al. 2003). The use of composted FYM is a common practice in Indian Himalayan villages (Gopinath et al. 2008). Farmers in Jahrkhand state of India use compressed cakes of plant material and flowers to make organic manure. Plant species like madhu (Madhuca indica), neem (Azadirachta indica) and karanj (Derris indica) are used to make cake and then mixed with leaves, flowers and FYM (Dey and Sarkar 2011). The use of organic manure such as farmyard manure (FYM) has been a traditional practice in China (Shen et al. 1997; Yang et al. 2004). In China, organic manure has been used since Shang dynasty 3000 BC (Liu et al. 2013). The use of FYM is a traditional practice in Kilimanjaro region of the South Africa. People in Kilimanjaro make FYM by using materials like livestock wastes including chicken and goat waste and ashes. It is locally called as Samadi or Boru in Kilimanjaro. It increases the soil fertility and prevents crop from insects (Kangalawe et al. 2014).

\subsection{Integrated crop-animal farming}

Crop-animal integrated farming is a well-recognized practice of smallholder farmers in Asia (Devendra and Thomas 2002a). Although based on crop production, integrated crop-animal farming is a backbone of smallscale Asian agriculture (Devendra and Thomas 2002b). Integrating animal component to crop is supportive for agrobiodiversity, food diversity and land resource management that strengthens the resilience of agroecosystem in changing climate. Rice-fish culture is an important farming practice that increases diversification, intensification, productivity, profitability with sustainable food production (Ahmed et al. 2007; Nhan et al. 2007; Ahmed and Garnett 2011). Further, it increases soil fertility through improving availability of phosphorous and nitrogen and thus decreases external input of chemical fertilisers and consequently lowering the GHGs emission (Giap et al. 2005; Dugan et al. 2006; Ahmed and Garnett 2011). It is a sustainable practice not only for food production but also for climate change mitigation, natural resource management and biodiversity conservation (Frei and Becker 2005; Datta et al. 2009; Jian et al. 2011). Rice-fish culture system is a sustainable method for using land and water resources, generating employment, enhancing farmers' income, providing nutritional security and reducing the risks of rice crop damage by natural disasters (Mishra and Mohanty 2004). After flooding, oxygen is swiftly depleted in the rice fields and this reducing condition promotes the methanogenic process (Liesack et al. 2000; Krüger et al. 2001). Fishes raised in the paddy fields obstruct the methanogenic process during their search of feed and consequently mitigating $\mathrm{CH}_{4}$ emission (Frei and Becker 2005).

The rice-fish co-culture system in Zhejiang Province, China is an age-old farming practice. It has been used by local farmers for more than 1200 years (Wang 1997; You 2006; Jian et al. 2011). This practice is recognized as the Globally Important Agricultural Heritage System (GIAHS) by the FAO, United Nations Development Programme (UNDP), and Global Environment Facility (GEF) (Jian et al. 2011). Integrated rice-fish cultivation is a traditional farming system in Bangladesh (Ahmed and Garnett 2011). It is based on sustainable utilization of various resources like water and land (Frei and Becker 2005). In India, ricefish culture is an age-old practice that dates back to about 1500 years (Mohanty et al. 2004; Mishra and Mohanty 2004). Besides fish, duck raising in paddy fields is also a prominent practice. Duck-rice-fish culture is an indigenous farming system in China for sustainable utilization of land and water resources (Juanwen et al. 2012). In paddy fields, fishes are reared which eat plant hoppers and weeds while providing nutrient for rice. Fishes also soften the soil and transport oxygen in water by their movement in rice field. Besides fishes, each household also raises ducks in their paddy fields. Ducks eat insects in the paddy field thus ensuring good rice harvest. Conventional rice culture needs intensive application of chemical fertilisers for enhancing yields. It is widely recognized that fertiliser application is reduced through rice-duck cultivation (Long et al. 2013).

\section{Traditional agriculture: a sustainable approach for climate change adaptation}

Adaptation contributes a significant role in climate change vulnerability assessment and policy framework to check climate change impacts (Fankhauser 1996; Smith and Lenhart 1996; Smit et al. 1999). Climate change adaptation is an adjustment to reduce vulnerability or enhance resilience in response to observed or expected changes in climate and associated extreme weather events (IPCC 2007b). Climate change adaptation is the need of hour to 
ensure global food security and environmental quality (Connor and Mínguez 2012; Sayer and Cassman 2013). Farmers in different regions have different perceptions and adaptation strategies to adjust with change in climate. Farmers' perception to climate change play a great role not only to adaptation strategies but also in designing policy and integration of scientific and indigenous knowledge for climate change adaptation (Juana et al. 2013; Ayal and Filho 2017; Woods et al. 2017). In agriculture, climate change adaptation is as old as the agriculture itself. Since the beginning of agriculture, peasants have been continually adjusting their agriculture practices with change in climatic conditions. (Burger 2015). Indigenous farmers have a long history of climate change adaptation through making changes in agriculture practices. The Institute of Advanced Studies at the United Nations University recently identified more than 400 examples of indigenous peoples' contribution in climate change monitoring, adaptation and mitigation (McLean 2010).

Integrating traditional knowledge into climate change policies paves the way for cost-effective and sustainable adaptation coupled with mitigation strategies (Nyong et al. 2007). Without adaptation, climate change is generally challenging for agricultural production. But through adaptation methods, climate change impacts can be minimized (Nordhaus 1991; Easterling et al. 1993; Rosenzwieg and Parry 1994; Fankhauser 1996; Smith 1996; Mendelsohn 1998; Wheaton and Maciver 1999). Environmental conditions, geographical location, socio-economic status, cultural differences and diverse knowledge systems influence perceptions of climate change and adaptation approaches (Saarinen 1976; Deressa et al. 2011; Wolf et al. 2013; Touch et al. 2016; Ayal and Filho 2017). Farmers with extensive knowledge about climate change and its impacts are better adjusted (Adger et al. 2003; Kemausuor et al. 2011; Akerlof et al. 2013; Tripathi and Singh 2013; Menapace et al. 2015; Tesfahunegn et al. 2016; Li et al. 2017). Shifting planting and harvesting dates, crop diversification, integrated crop-livestock farming, cropping drought-resistant varieties and high yielding water sensitive crops are some of the sustainable approaches to climate change adaptation (Bradshaw et al. 2004; Di Falco et al. 2011; Di Falco and Veronesi 2011; Moniruzzaman 2015). It has been observed that when compared to monoculture, polyculture systems exhibit a greater yield stability and less productivity decline during drought (Altieri and Nicholls 2008).

Indigenous knowledge should be used in climate change adaptation approaches and policies (Bernstein et al. 2008). Small farmers use several techniques to reduce climatedriven crop failure such as use of drought-tolerant local varieties, polyculture, agroforestry, water harvesting and conserving soil (Browder 1989; Altieri and Nicholls 2008;
Chhetri et al. 2012). Indigenous peasnats use various natural indicators to forecast the weather patterns such as changes in the behaviour of local flora and fauna (KalandaJoshua et al. 2011; Nkomwa et al. 2014). Farmers in Chagaka Village, Chikhwawa, Southern Malawi use several indicators for climate and weather prediction. According to these farmers, occurrence of grasshoppers and a bird called Chinkhaka flying in household vicinity indicates the drought. Moreover, shedding of leaves by Adonsonia digitata (baobab/mlambe), Cordyla africana (mtondo) and Faidherbia albida (nsangu) indicates the onset of rainfall and well distributed rainfall season (Nkomwa et al. 2014). Farmers of Cameroon use the height of an ant nest in trees or colour of frog to forecast the onset and cessation of rainy season as well as the quantity of rain (Molua 2006; Tingem and Rivington 2009).

Traditional farming systems promote agroecosystem sustainability through conserving soil, harvesting water and cropping varieties of crop under the conditions of water stress, limited resources and low level of technology (Altieri and Toledo 2005). In Ethiopia and South Africa, farmers use several drought adaptation strategies such as changing planting dates, adopting new crop varieties and migrating seasonally (Deressa et al. 2009; Bryan et al. 2009; Lei et al. 2016). Sweet potato is a traditional drought-tolerant and potential food security crop in South Africa (Motsa et al. 2015). In Ethiopia, farmers harvest rainwater through traditional water harvesting pits locally known as zai pits (Chhetri et al. 2012). Farmers of Zimbabwe acclimatize in drought conditions through switching to more drought-tolerant crop varieties (Matarira et al. 1996; Chhetri et al. 2012). Besides their medicinal, commercial and cultural values, traditional vegetables are also important for sustainable food production, climate change adaptation and environmental sustainability with minimum external input. Cucuminsmelo var. agrestis (kachri) is a drought-tolerant traditional vegetable with short growth cycles and it can survive in harsh climatic conditions of Rajasthan, India (Maurya et al. 2007; De la Peña et al. 2011; Hughes and Ebert 2013; Ebert 2014). Farmers in North-West Cambodia cultivate cassava in their fields. Cassava is a drought-resistant crop that can be grown in different soils and requires less management and generates extra income (Touch et al. 2016).

Framers in Bangladesh make changes in the selection of rice varieties during high temperature conditions. They replace rainfed variety such as Aman rice crop by irrigation based Boro, Aus and other rice crops (Moniruzzaman 2015). Farmers in Sahel, Africa adapt to climate change through making alterations in animal husbandry. They domesticate sheep (Capra) and goat in place of cattle (Bos) as formers have comparatively less feed requirements (Oba 1997). They also include diversity of herds in their 
husbandry practices to survive under extreme climate (Nyong et al. 2007). Bangladesh is one of the highly vulnerable countries to climate change impacts particularly floods and waterlogging (IPCC 2012). Floating agriculture is an indigenous method of farming in the Southern floodplains of Bangladesh. It is highly self innovated farming technique in which crops and vegetables are grown on floating platforms (beds). These floating beds are built through utilizing locally available materials such as water hyacinth and other aquatic weeds (Chowdhury and Moore 2017).

\section{Conclusion and recommendations}

Agriculture is one of the leading sectors that contribute to global GHG emission. Utilization of traditional agriculture knowledge for food production is an age-old practice. Traditional agriculture is still a growing concern for widespread use and inclusion in policy framework. This review article advocates traditional agriculture as a climate-smart agriculture approach to sustainable food production. Traditional agricultural practices have potentials to adapt and mitigate climate change through their agroecological features. They increase agrobiodiversity and resilience of agroecosystems. Moreover, they are lowcost, energy-efficient and based on locally available resources. Indigenous people are custodians of traditional agriculture knowledge. Traditional agriculture can be adopted as an alternative method for sustainable food production in changing climate. Besides mitigating climate change, traditional agriculture is also helpful for human health safety, natural resource management, energy conservation and socio-ecological integrity. Agroforestry, intercropping, crop rotation, cover cropping, traditional organic composting and integrated crop-animal farming can be adopted as the model practices for climate-smart approach in agriculture. These practices not only mitigate climate change but also enhance agricultural sustainability.

The necessity for enhancing food production in climate change scenario has been much debated. Traditional practices coupled with modern sustainable farming practices would be a noble choice for climate change mitigation and adaptation. The following recommendations are suggested for the sustainability of food production while addressing climate change issues.

1. Increasing food productivity while addressing climate change impacts needs the integration of traditional and modern agricultural practices. Climate-smart agriculture practices both modern as well as traditional should be encouraged and used widely.
2. Adoption of sustainable practices for socio-economic development would be a better decision to make a balance between environment, society and economy.

3. Indigenous cultures, their languages, rituals, traditions and practices should be respected and campaigned positively for their preservation.

4. Farmers should be given sufficient crop insurance during climate-driven crop failure or during crop damage by natural disasters such as flood and fire.

5. More inclusive research focused on the identification and exploration of traditional agriculture knowledge at larger scale is the need of hour.

6. There is an urgent need to develop a concrete policy framework to protect and utilize traditional agricultural practices.

7. The use of inorganic fertilisers should be minimized and substituted by organic compost to reduce the GHGs emission.

8. Fossils fuels utilization should be reduced and use of biofuels should be encouraged for climate change mitigation.

9. There is a pressing need to enhance the agrobiodiversity for making agroecosystem more resilient to climate change.

10. Cooperation and coordination between various stakeholders such as local people, policy makers and researchers is urgently required to form effective strategies for climate change mitigation and adaptation.

Acknowledgements We gratefully acknowledge the University Grants Commission, Ministry of Human Resource Development, Government of India, for providing financial support in the form of Junior Research Fellowship (JRF) to Rinku Singh. We are thankful to the Director, Institute of Environment and Sustainable Development and Coordinator, Mahamana Center of Excellence for Climate Change Research, Banaras Hindu University, Varanasi, for providing infrastructure throughout the process.

\section{References}

Adams MW, Ellingboe AH, Rossman EC (1971) Biological uniformity and disease epidemics. Bioscience 21:1067-1070. doi:10. 2307/1295991

Adger WN, Hug S, Brown K, Conway D, Hume M (2003) Adaptation to climate change in developing world. Prog Dev Stud 3(3):179195. doi:10.1191/1464993403ps060oa

Adger WN, Arnell NW, Tompkins EL (2005) Successful adaptation to climate change across scales. Glob Environ Change 15(2):7786

Agrawal A (1995) Indigenous and scientific knowledge: some critical comments. Indigenous Knowledge \& Development Monitor 3:35 
Aguilar-Jiménez CE, Tolón-Becerra A, Lastra-Bravo XB (2013) Traditional agroecosystems vs. alternative agroecosystems in maize in Chiapas Mexico. J Anim Plant Sci 23:633-646

Ahmed N, Garnett ST (2011) Integrated rice-fish farming in Bangladesh: meeting the challenges of food security. Food Secur 3(1):81-92

Ahmed N, Wahab MA, Thilsted SH (2007) Integrated aquacultureagriculture systems in Bangladesh: potential for sustainable livelihoods and nutritional security of the rural poor. Aquac Asia 12(1):14-22

Akerlof K, Maibach EW, Fitzgerald D, Cedeno AY, Neuman A (2013) Do people "personally experience" global warming, and if so how, and does it matter? Glob Environ Chang 23:81-91. doi:10.1016/j.gloenvcha.2012.07.006

Albrecht A, Kandji ST (2003) Carbon sequestration in tropical agroforestry systems. Agric Ecosyst Environ 99(1):15-27

Alidadi H, Parvaresh AR, Shahmansouri MR, Pourmoghadas H (2005) Combined compost and vermicomposting process in the treatment and bioconversion of sludge. Iran J Environ Health Sci Eng 2:251-254

Altieri MA (1993) Ethnoscience and biodiversity: key elements in the design of sustainable pest management systems for small farmers in developing countries. Agr Ecosyst Environ 46(1-4):257-272

Altieri MA (1999a) Applying agroecology to enhance the productivity of peasant farming systems in Latin America. Environ Dev Sustain 1(3): 197-217

Altieri MA (1999b) The ecological role of biodiversity in agroecosystems. Agr Ecosyst Environ 74(1):19-31

Altieri MA (2000) Multifunctional dimensions of ecologically based agriculture in Latin America. Int J Sustain Dev World Ecol 7:6275

Altieri MA (2002) Agroecology: the science of natural resource management for poor farmers in marginal environments. Agr Ecosyst Environ 93(1):1-24

Altieri MA (2004) Linking ecologists and traditional farmers in the search for sustainable agriculture. Front Ecol Environ 2(1):3542

Altieri MA (2009) Agroecology, small farms, and food sovereignty. Mon Rev 61(3): 102

Altieri MA, Merrick L (1987) In situ conservation of crop genetic resources through maintenance of traditional farming systems. Econ Bot 41(1):86-96

Altieri MA, Nicholls CI (2008) Scaling up agroecological approaches for food sovereignty in Latin America. Development 51(4):472480

Altieri MA, Toledo VM (2005) Natural resource management among small-scale farmers in semi-arid lands: building on traditional knowledge and agroecology. Ann Arid Zone 44(3/4):365

Altieri MA, Anderson M, Merrick LC (1987) Peasant agriculture and the conservation of crop and wild plant resources. Conserv Biol 1(1):49-58

Altieri MA, Nicholls CI, Henao A, Lana MA (2015) Agroecology and the design of climate change-resilient farming systems. Agron Sustain Dev 35(3):869-890

Alvarez R, Steinbach HS, De Paepe JL (2017) Cover crop effects on soils and subsequent crops in the pampas: a meta-analysis. Soil Till Res 170:53-65

Anex RP, Lynd LR, Laser MS, Heggenstaller AH, Liebman M (2007) Potential for enhanced nutrient cycling through coupling of agricultural and bioenergy systems. Crop Sci 47:1327-1335

Ayal DY, Leal Filho W (2017) Farmers' perceptions of climate variability and its adverse impacts on crop and livestock production in Ethiopia. J Arid Environ 140:20-28

Bandara JS, Cai Y (2014) The impact of climate change on food crop productivity, food prices and food security in South Asia. Econ Anal Policy 44(4):451-465
Barankova Z, Dobrovodska M, Stefunkova D, Babicova D, Moyzeova M, Petrovic F (2011) Participation of local people on identifying the landscape values and future development in historical agricultural landscapes. Ekologia 30:216-228. doi:10. 4149/ekol_2011_02_216

Basche AD, Kaspar TC, Archontoulis SV, Jaynes DB, Sauer TJ, Parkin TB, Miguez FE (2016) Soil water improvements with the long-term use of a winter rye cover crop. Agric Water Manag 172:40-50

Beer J, Bonnemann A, Chavez W, Fassbender HW, Imbach AC, Martel I (1990) Modelling agroforestry systems of cacao (Theobroma cacao) with laurel (Cordia alliodora) or poro (Erythrina poeppigiana) in Costa Rica. Agrofor Syst 12(3):229_ 249

Bernstein L, Bosch P, Canziani O, Chen Z, Christ R, Riahi K (2008) IPCC 2007: climate change 2007-synthesis report. IPCC, Bangkok

Berzseny Z, Gyrffy B (1997) Effect of crop rotation and fertilization on maize and wheat yield stability in long-term experiments. Agrok ma s Talajtan 46:377-398

Bot A, Benites J (2005) The importance of soil organic matter: key to drought-resistant soil and sustained food production (No. 80). Food and Agriculture Organization, Rome

Bouwman AF, Boumans LJM, Batjes NH (2002) Emissions of N2O and NO from fertilized fields: summary of available measurement data. Global Biogeochem Cycles 16(4):1080

Boyce JK (2006) A future for small farms? Biodiversity and sustainable agriculture. In: Boyce JK, Cullenberg S, Pattanaik PK, Pollin R (eds) Human development in the era of globalization. Edward Elga, Cheltenham, pp 83-104

Bradshaw B, Dollan H, Smit B (2004) Farm-level adaptation to climate variability and change: crop diversification in the Canadian prairies. Clim Chang 67:119-141

Brandt P, Kvakić M, Butterbach-Bahl K, Rufino MC (2015) How to target climate-smart agriculture? Concept and application of the consensus-driven decision support framework "target CSA". Agric Syst 151:234

Bridge J (1996) Nematode management in sustainable and subsistence agriculture. Annu Rev Phytopathol 34(1):201-225

Browder JO (1989) Fragile lands in Latin America: strategies for sustainable development. Westview Press, Boulder

Bryan E, Deressa TT, Gbetibouo GA, Ringler C (2009) Adaptation to climate change in Ethiopia and South Africa: options and constraints. Environ Sci Policy 12:413-426

Bullock DG (1992) Crop rotation. Crit Rev Plant Sci 11(4):309-326

Burger $P$ (2015) Climate change mitigation and adaptation in drylands. Action by dryland members. https://dry-net.org/wpcontent/uploads/2015/09/Climate-Change-Mitigation-and-Adap tation-in-Drylands.pdf

Campbell BM, Thornton P, Zougmoré R, Van Asten P, Lipper L (2014) Sustainable intensification: What is its role in climate smart agriculture? Curr Opin Environ Sustain 8:39-43

Challinor AJ, Watson J, Lobell DB, Howden SM, Smith DR, Chhetri N (2014) A meta-analysis of crop yield under climate change and adaptation. Nat Clim Change 4:287-291

Cha-un N, Chidthaisong A, Yagi K, Sudo S, Towprayoon S (2017) Greenhouse gas emissions, soil carbon sequestration and crop yields in a rain-fed rice field with crop rotation management. Agr Ecosyst Environ 237:109-120

Cherr CM, Scholberg JMS, McSorley R (2006) Green manure approaches to crop production: a synthesis. Agron J 98:302-319

Chhatre A, Agrawal A (2008) Forest commons and local enforcement. Proc Nati Acad Sci USA 105:13286-13291

Chhetri N, Chaudhary P, Tiwari PR, Yadaw RB (2012) Institutional and technological innovation: Understanding agricultural adaptation to climate change in Nepal. Appl Geogr 33:142-150 
Chowdhury RB, Moore GA (2017) Floating agriculture: a potential cleaner production technique for climate change adaptation and sustainable community development in Bangladesh. J Clean Prod 150:371-389

Connor DJ, Mínguez MI (2012) Evolution not revolution of farming systems will best feed and green the world. Glob Food Secur 1:106-113

Cooper RJ, Aziza JH, Hiscocka KM, Lovetta AA, Dugdalea SJ, Sünnenberga G, Noble L, Beamish J, Hovesen P (2017) Assessing the farm-scale impacts of cover crops and noninversion tillage regimes on nutrient losses from an arable catchment. Agr Ecosyst Environ 237:181-193

Coulibaly JY, Chiputwa B, Nakelse T, Kundhlande G (2017) Adoption of agroforestry and the impact on household food security among farmers in Malawi. Agric Syst 155:52-69

Crutzen PJ (2002) Geology of mankind: the Anthropocene. Nature 415:23

Dabney SM, Delgado JA, Reeves DW (2001) Using winter cover crops to improve soil and water quality. Commun Soil Sci Plant Anal 32:1221-1250. doi:10.1081/CSS-100104110

Datta A, Nayak DR, Sinhababu DP, Adhya TK (2009) Methane and nitrous oxide emissions from an integrated rainfed ricefish farming system of Eastern India. Agr Ecosyst Environ 129:228237

De la Peña RC, Ebert AW, Gniffke P, Hanson P, Symonds RC (2011) Genetic adjustment to changing climates: vegetables. In: Yadav SS, Redden RJ, Hatfield JL, Lotze-Campen H, Hall AE (eds) Crop adaptation to climate change, 1st edn. Chichester, UK, John Wiley \& Sons Ltd, pp 396-410

Denevan WM (1995) Prehistoric agricultural methods as models for sustainability. Adv Plant Pathol 11(1995):21-43

Deressa TT, Hassan RM, Ringler C, Alemu T, Yesuf M (2009) Determinants of farmers' choice of adaptation methods to climate change in the Nile Basin of Ethiopia. Glob Environ Change 19(2):248-255

Deressa TT, Hassan RM, Ringler C (2011) Perception of and adaptation to climate change by farmers in the Nile basin of Ethiopia. J Agric Sci 149:23-31

Deryng D, Conway D, Ramankutty N, Price J, Warren R (2014) Global crop yield response to extreme heat stress under multiple climate change futures. Environ Res Lett 9(3):034011

Devendra C, Thomas D (2002a) Crop-animal interactions in mixed farming systems in Asia. Agric Syst 71(1):27-40

Devendra C, Thomas D (2002b) Smallholder farming systems in Asia. Agric Syst 71(1):17-25

Dey P, Sarkar AK (2011) Revisiting indigenous farming knowledge of Jharkhand (India) for conservation of natural resources and combating climate change. Indian J Tradit Knowl 10(1):71-79

Di Falco S, Veronesi M (2011) On adaptation to climate change and risk exposure in the Nile basin of Ethiopia. IED Working Paper 15

Di Falco S, Veronesi M, Yesuf M (2011) Does adaptation to climate change provide food security? Microevidence from Ethiopia. Am J Agric Econ 93(3):829-846

Diaz-Zorita M, Buschiazzo DE, Peinemann N (1999) Soil organic matter and wheat productivity in the semiarid Argentine Pampas. Agron J 91(2):276-279

Ding J, Jiang X, Guan D, Zhao B, Ma M, Zhou B, Li J (2017) Influence of inorganic fertilizer and organic manure application on fungal communities in a long-term field experiment of Chinese Mollisols. Appl Soil Ecol 111:114-122

Drinkwater LE, Wagoner P, Sarrantonlo M (1998) Legume based cropping systems have reduced carbon and nitrogen losses. Nature 396(6708):262-265

Duchene O, Vian JF, Celette F (2017) Intercropping with legume for agroecological cropping systems: Complementarity and facilitation processes and the importance of soil microorganisms: a review. Agr Ecosyst Environ 240:148-161

Dugan P, Dey MM, Sugunan VV (2006) Fisheries and water productivity in tropical river basins: enhancing food security and livelihoods by managing water for fish. Agric Water Manag 80:262-275

Dury J, Schaller N, Garcia F, Reynaud A, Bergez JE (2012) Models to support cropping plan and crop rotation decisions: a review. Agron Sustain Dev 32(2):567-580

Duval ME, Galantini JA, Capurro JE, Martinez JM (2016) Winter cover crops in soybean monoculture: effects on soil organic carbon and its fractions. Soil Till Res 161:95-105

Dweba TP, Mearns MA (2011) Conserving indigenous knowledge as the key to the current and future use of traditional vegetables. Int J Inf Manage 31(6):564-571

Eakin H, Webhe M, Avila C, Sanchez Torres G, Bojorquez-Tapia LA (2007) Climate change and vulnerability. Earthscan, London

Easterling WE, Crosson PR, Rosenberg NJ, McKenney MS, Katz LA, Lemon KM (1993) Agricultural impacts of and responses to climate change in the Missouri-Iowa-NebraskaKansas region. Clim Change 24(1-2):23-62

Ebert AW (2014) Potential of underutilized traditional vegetables and legume crops to contribute to food and nutritional security, income and more sustainable production systems. Sustainability 6(1):319-335

Eitzinger J, Thaler S, Schmid E, Strauss F, Ferrise R, Moriondo M, Bindi M, Palosuo T, Roetter R, Kersebaum KC, Olesen JE, Patil RH, Şaylan L, Çaylac ÇB (2013) Sensitivities of crop models to extreme weather conditions during flowering period demonstrated for maize and winter wheat in Austria. J Agric Sci 151 (06):813-835. doi:10.1017/S0021859612000779

Ellis E, Wang SM (1997) Sustainable traditional agriculture in the Tai Lake Region of China. Agric Ecosyst Environ 61(2-3):177-193

Evenson RE, Gollen D (2003) Assessing the impact of the green revolution, 1960 to 2000. Science 300:758-762

Fageria NK, Baligar VC, Bailey BA (2005) Role of cover crops in improving soil and row crop productivity. Commun Soil Sci Plant Anal 36:2733-2757

Fankhauser S (1996) The potential costs of climate change adaptation. In: Smith JB, Bhatti N, Menzhulin G, Bennioff R, Budyko M, Campos M, Jallow B, Rijsberman F (eds) Adapting to climate change: an international perspective. Springer, New York, pp 80-96

FAO, Food and Agricultural Organization (2009) First fruits of plant gene pact (June 21, 2009). http://www.fao.org/news/story/0/ item/20162/icode/en/[hereinafterFirstFruits]

FAO, Food and Agricultural Organization (2010) Climate smart agriculture: policies, practices and financing for food security. Adaptation and Mitigation, Food and Agriculture Organization of the United Nations (FAO), Rome, Italy

FAO, Food and Agriculture Organization (2011a) Green manure/cover crops and crop rotation in conservation agriculture on small farms. Plant Production and Protection Division, Food and Agriculture Organization of the United Nations Rome

FAO, Food and Agriculture Organization of the United Nations (2011b) Facts and figures: people and forests [online]. http:// www.fao.org/forestry/28811/en/. Accessed 11 August 2012

FAO, Food and Agricultural Organization (2016) The State of Food and Agriculture, Climate Change, Agriculture and Food Security. Food and Agriculture Organization of the United Nations Rome, 2016. www.fao.org

Fernandez PG (1994) Indigenous seed practices for sustainable agriculture. Indig Knowl Dev Monit 2(2):9-12

Fisher B, Turner RK, Morling P (2009) Defining and classifying ecosystem services for decision making. Ecol Econ 68(3):643653 
Fischer J, Hartel T, Kuemmerle T (2012) Conservation policy in traditional farming landscapes. Conserv Lett 5(3):167-175

Fließbach A, Oberholzer HR, Gunst L, Mäder P (2007) Soil organic matter and biological soil quality indicators after 21 years of organic and conventional farming. Agr Ecosyst Environ 118 (1):273-284

Forte A, Fagnano M, Fierro A (2017) Potential role of compost and green manure amendment to mitigate soil GHGs emissions in Mediterranean drip irrigated maize production systems. J Environ Manage 192:68-78

Francis CA (1986) Distribution and importance of multiple cropping. In: Francis CA (ed) Multiple cropping systems. MacMillan Publishing Company, New York, USA

Fraser JA, Frausin V, Jarvis A (2015) An intergenerational transmission of sustainability? Ancestral habitus and food production in a traditional agro-ecosystem of the Upper Guinea Forest, West Africa. Glob Environ Change 31:226-238

Frasier I, Quiroga A, Noellemeyer E (2016) Effect of different cover crops on $\mathrm{C}$ and $\mathrm{N}$ cycling in sorghum NT systems. Sci Total Environ 562:628-639

Frei M, Becker K (2005) Integrated rice-fish culture: coupled production saves resources. Nat Resour Forum 29:135-143

Fullen MA, Auerswald K (1998) Effect of grass ley set-aside on runoff, erosion and organic matter levels in sandy soil in east Shropshire, UK. Soil Till Res 46:41-49

Gabriel JL, Quemada M (2011) Replacing bare fallow with cover crops in a maize cropping system: yield, $\mathrm{N}$ uptake and fertiliser fate. Eur J Agron 34:133-143

Ge Y, Zhang JB, Zhang LM, Yang M, He JZ (2008) Long-term fertilization regimes affect bacterial community structure and diversity of an agricultural soil in Northern China. J Soils Sediments 8:43-50

Giap DH, Yi Y, Lin CK (2005) Effects of different fertilization and feeding regimes on the production of integrated farming of rice and prawn Macrobrachium rosenbergii (De Man). Aquac Res 36:292-299

Gliessman SR (1998) Agroecology: ecological process in sustainable agriculture. Ann Arbor Press, Ann Arbor

Godfray HCJ, Beddington JR, Crute IR, Haddad L, Lawrence D, Muir JF, Pretty J, Robinson S, Thomas SM, Toulmin C (2010) Food security: the challenge of feeding 9 billion people. Science 327:812-818

Gomes J, Bayer C, de Souza CF, de Cassia Piccolo M, Zanatta JA, Vieira FCB, Six J (2009) Soil nitrous oxide emissions in longterm cover cropsbased rotations under subtropical climate. Soil Till Res 106:36-44

Gonzalez CG (2010) Comment, the global food crisis: law, policy, and the elusive quest for justice. Yale Hum Rts Dev LJ 13:462, 468 (see also FOWLER \& MOONEY, supra note 2, at 42)

Gonzalez CG (2011) Climate change, food security, and agrobiodiversity: toward a just, resilient, and sustainable food system. Fordham Environ Law Rev 22:493-522

Gopinath KA, Saha S, Mina BL, Pande H, Kundu S, Gupta HS (2008) Influence of organic amendments on growth, yield and quality of wheat and on soil properties during transition to organic production. Nutr Cycl Agroecosyst 82(1):51-60

Gornall J, Betts R, Burke E, Clark R, Camp J, Willett K, Wiltshire A (2010) Implications of climate change for agricultural productivity in the early twenty-first century. Philos Trans R Soc London B Biol Sci 365(1554):2973-2989

Goyal S, Dhull SK, Kapoor KK (2005) Chemical and biological changes during composting of different organic wastes and assessment of compost maturity. Bioresour Technol 96 (14): 1584-1591

Grainger-Jones E (2011) Climate-smart smallholder agriculture: What's different? No. 3. IFAD Occasional Paper, Rome
Gselman A, Kramberger B (2008) Benefits of winter legume cover crops require early sowing. Aust J Agric Res 59:1156-1163

Halsnæs K, Shukla P, Ahuja D, Akumu G, Beale R, Edmonds J, Gollier C, Grübler A, Ha Duong M, Markandya A, McFarland M, Nikitina E, Sugiyama T, Villavicencio A, Zou J (2007) 2007: Framing issues. In: Metz B, Davidson OR, Bosch PR, Dave R, Meyer LA (eds) Climate change 2007: mitigation. Contribution of working group III to the fourth assessment report of the intergovernmental panel on climate change. Cambridge University Press, Cambridge

Harrop SR (2007) Traditional agricultural landscapes as protected areas in international law and policy. Agric Ecosyst Environ 121:296e307. doi:10.1016/j.agee.2006.12.020

Hartel T, Schweiger O, Ollerer K, Cogalniceanu D, Arntzen JW (2010) Amphibian distribution in a traditionally managed rural landscape of Eastern Europe: probing the effect of landscape composition. Biol Conserv 143:1118-1124

Harvey CA, Chacón M, Donatti CI, Garen E, Hannah L, Andrade A, Bede L, Brown D, Calle A, Chará J, Clement C, Gray E, Hoang MH, Minang P, Rodríguez AM, Seeberg-Elverfeldt C, Semroc B, Shames S, Smukler S, Somarriba E, Torquebiau E, van Etten J, Wollenberg E (2014) Climate-smart landscapes: opportunities and challenges for integrating adaptation and mitigation in tropical agriculture. Conserv Lett 7:77-90. doi:10.1111/conl. 12066

Hauggaard-Nielsen H, Jørnsgaard B, Kinane J, Jensen ES (2008) Grain legume-cereal intercropping: The practical application of diversity, competition and facilitation in arable and organic cropping systems. Renew Agric Food Syst 23(01):3-12

Hauggaard-Nielsen H, Lachouani P, Knudsen MT, Ambus P, Boelt B, Gislum R (2016) Productivity and carbon footprint of perennial grass-forage legume intercropping strategies with high or low nitrogen fertilizer input. Sci Total Environ 54:1339-1347

Heinemann JA, Massaro M, Coray DS, Agapito-Tenfen SZ, Wen JD (2013) Sustainability and innovation in staple crop production in the US Midwest. Int J Agric Sustain. doi:10.1080/14735903. 2013.806408

Herzog F (1994) Multipurpose shade trees in coffee and plantations in C^ote d'Ivoire. Agrofor Syst 27:259-268

Hillel D, Rosenzweig C (2010) Climate change and agroecosystems: main findings and future research directions ICP series on climate change impacts, adaptation, and mitigation, vol 1 . In: Hillel D, Rosenzweig C (eds) Handbook of climate change and agroecosystems impacts, adaptation, and mitigation. Imperial College Press, London

Hobbs PR, Sayre K, Gupta R (2008) The role of conservation agriculture in sustainable agriculture. Philos Trans $\mathrm{R}$ Soc London B Biol Sci 363(1491):543-555

Howden SM, Soussana JF, Tubiello FN, Chhetri N, Dunlop M, Meinke H (2007) Adapting agriculture to climate change. Proc Natl Acad Sci 104(50):19691-19696

Howes M, Chambers R (1980) Indigenous knowledge: analysis, implications and issues. In: Brokensha D (ed) Indigenous knowledge and development. University Press of America, Lanham, pp 323-334

Hu F, Feng F, Zhao C, Chai Q, Yu A, Yin W, Gan Y (2017) Integration of wheat-maize intercropping with conservation practices reduces $\mathrm{CO}_{2}$ emissions and enhances water use in dry areas. Soil Till Res 169:44-53

Huang M, Shao M, Zhang L, Li Y (2003) Water use efficiency and sustainability of different long-term crop rotation systems in the Loess Plateau of China. Soil Till Res 72(1):95-104

Hughes JDA, Ebert AW (2013) Research and development of underutilized plant species: the role of vegetables in assuring food and nutritional security. In: Massawe F, Mayes S, Alderson $\mathrm{P}$ (eds) Proceedings of the 2nd international symposium on 
underutilized plant species: crops for the future-beyond food security, vol 2. International Society for Horticultural Sciences (ISHS), Korbeek-Lo, pp 79-91

Hwang HY, Kim GW, Kim SY, Haque MM, Khan MI, Kim PJ (2017) Effect of cover cropping on the net global warming potential of rice paddy soil. Geoderma 292:49-58

IASC, Inter-Agency Standing Committee (2010) Addressing the humanitarian challenges of climate change-regional and national perspectives, finding from the iasc regional and national consultations. http://www.humanitarianinfor/IASC. Accessed 16 Sept 2014

IPCC, Intergovernmental Panel on Climate Change (2000) Land use, land-use change, and forestry. Cambridge University Press, Cambridge

IPCC, Intergovernmental Panel on Climate Change (2007a) Synthesis report. Contribution of working groups I, Ii and Iii to the fourth assessment report of the intergovernmental panel on climate change. IPCC, Geneva, Switzerland

IPCC, Intergovernmental Panel on Climate Change (2007b) Climate Change 2007: impacts, adaptation and vulnerability. In: Parry ML, Canziani OF, Palutikof JP, van der Linden PJ, Hanson CE (eds) Contribution of working group II to the fourth assessment report of the intergovernmental panel on climate change. Cambridge University Press, Cambridge, p 976

IPCC, Intergovernmental Panel on Climate Change (2012) In: Field CB, Barros V, Stocker TF, Qin D, Dokken, DJ, Ebi KL, Mastrandrea MD, Mach KJ, Plattner GK, Allen SK, Tignor M, Midgley PM (eds) Managing the risks of extreme events and disasters to advance climate change adaptation. Cambridge University Press, Cambridge, p 582

IPCC, Intergovernmental Panel on Climate Change (2013) Climate change 2013: The physical science basis. Contribution of working group I to the fifth assessment report of the intergovernmental panel on climate change. Cambridge University Press, Cambridge

IPCC, Intergovernmental Panel on Climate Change (2014) Summary for policymakers. Fifth assessment report of the intergovernmental panel on climate change. Cambridge University Press, Cambridge

Islam MT, Nursey-Bray M (2017) Adaptation to climate change in agriculture in Bangladesh: the role of formal institutions. J Environ Manage 200:347-358

Jackson LE, Pascual U, Hodgkin T (2007) Utilizing and conserving agrobiodiversity in agricultural landscapes. Agr Ecosyst Environ 121(3):196-210

Jahanzada E, Barkera AV, Hashemia M, Sadeghpourc A, Eatona T, Park Y (2017) Improving yield and mineral nutrient concentration of potato tubers through cover cropping. Field Crops Res 212:45-51

Jarecki MK, Lal R (2003) Crop management for soil carbon sequestration. Crit Rev Plant Sci 22(6):471-502

Jenkinson DS, Bradbury NJ, Coleman K (1994) How the Rothamsted classical experiments have been used to develop and test models for the turnover of carbon and nitrogen in soil. In: Leigh RA, Johnston AE (eds) Long-term experiments in agricultural and ecological sciences. CAB International, Wallingford, pp. 117138

Jensen ES, Peoples MB, Hauggaard-Nielsen H (2010) Faba bean in cropping systems. Field Crop Res 115:203-216

Jian XIE, Xue WU, Tang JJ, Zhang JE, Luo SM, Xin C (2011) Conservation of traditional rice varieties in a globally important agricultural heritage system (GIAHS): rice-fish co-culture. Agric Sci China 10(5):754-761

Johns T, Powell B, Maundu P, Eyzaguirre PB (2013) Agricultural biodiversity as a link between traditional food systems and contemporary development, social integrity and ecological health. J Sci Food Agric 93(14):3433-3442

Johnston AE (1973) The effects of ley and arable cropping systems on the amount of organic matter in the Rothamstead and Woburn Ley-Arable Experiments. Rothamstead Report for 1972 Part 2, 131: 159

Johnston AE (1994) In: Leigh RA, Johnston AE (eds) In long-term experiments in agricultural and ecological sciences. $\mathrm{CAB}$ International, Wallingford, pp 9-37

Jose S (2009) Agroforestry for ecosystem services and environmental benefits: an overview. Agrofor Syst 76:1-10

Juana J, Kahaka Z, Okurut F (2013) Farmers' perceptions and adaptations to climate change in sub-Sahara Africa: a synthesis of empirical studies and implications for public policy in African agriculture. J Agric Sci 5(4):2013

Juanwen Y, Quanxin W, Jinlong L (2012) Understanding indigenous knowledge in sustainable management of natural resources in China: taking two villages from Guizhou Province as a case. For Policy Econ 22:47-52

Juárez MFD, Prähauser B, Walter A, Insam H, Franke-Whittle IH (2015) Co-composting of biowaste and wood ash, influence on a microbially driven-process. Waste Manag 46:155-164

Jungerius PD (1985) Perception and use of the physical environment in peasant societies. Geographical Papers, vol 93. Department of Geography, University of Reading, England, p 19

Kalanda-Joshua M, Ngongondo C, Chipeta L, Mpembeka F (2011) Integrating indigenous knowledge with conventional science: enhancing localised climate and weather forecasts in Nessa Mulanje, Malawi. J Phys Chem Earth 36(14-15):996-1003

Kangalawe RY, Noe C, Tungaraza FS, Naimani G, Mlele M (2014) Understanding of traditional knowledge and indigenous institutions on sustainable land management in Kilimanjaro Region, Tanzania. Open J Soil Sci 4(13):469

Kemausuor F, Dwamena E, Bart-Plange A, Nicholas Kyei-Baffour N (2011) Farmers' perception of climate change in the EjuraSekyedumase district of Ghana. ARPN J Agric Biol Sci 6 (10):26-37

Kongsager R, Locatelli B, Chazarin F (2016) Addressing climate change mitigation and adaptation together: a global assessment of agriculture and forestry projects. Environ Manage 57(2):271-282

Koohafkan P, Altieri MA (2010) Globally important agricultural heritage systems: a legacy for the future. UNFAO, Rome

Kremen C, Miles A (2012) Ecosystem services in biologically diversified versus conventional farming systems: benefits, externalities, and trade-offs. Ecol Soc 17(4):40

Krüger M, Frenzel P, Conrad R (2001) Microbial processes influencing methane emission from rice fields. Glob Change Biol 7(1):49-63

Kuivanen KS, Michalscheck M, Descheemaeker K, Adjei-Nsiah S, Mellon-Bedi S, Groot JCJ, Alvarez S (2016) A comparison of statistical and participatory clustering of smallholder farming systems: a case study in Northern Ghana. J Rural Stud 45:184198

Kumara PR, Munasinghe ES, Rodrigo VHL, Karunaratna AS (2016) Carbon footprint of rubber/sugarcane intercropping system in Sri Lanka: a case study. Proc Food Sci 6:298-302

Kuniyal JC, Vishvakarma SC, Singh GS (2004) Changing crop biodiversity and resource use efficiency of traditional versus introduced crops in the cold desert of the northwestern Indian Himalaya: a case of the Lahaul valley. Biodivers Conserv 13 (7):1271-1304

Lal R (2004) Soil carbon sequestration to mitigate climate change. Geoderma 123:1-22

Lal R (2008) Carbon sequestration. Philos Trans R Soc B Biol Sci 363 (1492):815-830 
Lal R (2011) Sequestering carbon in soils of agro-ecosystems. Food Policy 36:S33-S39

Lasco RD, Delfino RJP, Catacutan DC, Simelton ES, Wilson DM (2014) Climate risk adaptation by smallholder farmers: the roles of trees and agroforestry. Curr Opin Environ Sustain 6:83-88

Latati M, Pansu M, Drevon JJ, Ounane SM (2013) Advantage of intercropping maize (Zea mays L.) and common bean (Phaseolus vulgaris L.) on yield and nitrogen uptake in Northeast Algeria. Int J Res Appl Sci 1:1-7

Latati M, Aouiche A, Tellah S, Laribi A, Benlahrech S, Kaci G, Ounane SM (2017) Intercropping maize and common bean enhances microbial carbon and nitrogen availability in low phosphorus soil under Mediterranean conditions. Eur J Soil Biol 80:9-18

Lazali M, Brahimi S, Merabet C, Latati M, Benadis C, Maougal RT, Ounane SM (2016) Nodular diagnosis of contrasting recombinant inbred lines of Phaseolus vulgaris in multi-local field tests under Mediterranean climate. Eur J Soil Biol 73:100-107

Lehmann J, Kleber M (2015) The contentious nature of soil organic matter. Nature 528(7580):60-68

Lei Y, Liu C, Zhang L, Luo S (2016) How smallholder farmers adapt to agricultural drought in a changing climate: A case study in southern China. Land Use Policy 55:300-308

Li Z, Lu H, Ren L, He L (2013) Experimental and modeling approaches for food waste composting: a review. Chemosphere 93:1247-1257

Li X, Sorensen P, Li F, Petersen SO, Olensen JE (2015) Quantifying biological nitrogen fixation of different catch crops, and residual effects of roots and tops on nitrogen uptake in barley using in situ $15 \mathrm{~N}$ labelling. Plant Soil 395:273-287

Li S, Juhász-Horváth L, Harrison PA, Pintér L, Rounsevell MD (2017) Relating farmer's perceptions of climate change risk to adaptation behaviour in Hungary. J Environ Manage 185:21-30

Liesack W, Schnell S, Revsbech NP (2000) Microbiology of flooded rice paddies. FEMS Microbiol Rev 24(5):625-645

Lieskovský J, Bezák P, Špulerová J, Lieskovský T, Koleda P, Dobrovodská M, Gimmi U (2015) The abandonment of traditional agricultural landscape in Slovakia-analysis of extent and driving forces. J Rural Stud 37:75-84

Lin BB (2011) Resilience in agriculture through crop diversification: adaptive management for environmental change. Bioscience 61 (3): $183-193$

Linares AM (2007) Forest planning and traditional knowledge in collective woodlands of Spain: the dehesa system. For Ecol Manage 249(1):71-79

Lipper L, Thornton P, Campbell BM, Baedeker T, Braimoh A, Bwalya M, Hottle R (2014) Climate-smart agriculture for food security. Nat Clim Change 4(12):1068-1072

Liu Y, Duan M, Yu Z (2012) Agricultural landscapes and biodiversity in China. Agric Ecosyst Environ. doi:10.1016/j.agee.2011.05.009

Liu Y, Duan M, Yu Z (2013) Agricultural landscapes and biodiversity in China. Agr Ecosyst Environ 166:46-54

Liu Y, Zhou Z, Zhang X, Xu X, Chen H, Xiong Z (2015) Net global warming potential and greenhouse gas intensity from the double rice system with integrated soil-crop system management: a three-year field study. Atmos Environ 116:92-101

Liu X, Lehtonen H, Purola T, Pavlova Y, Rötter R, Palosuo T (2016) Dynamic economic modelling of crop rotations with farm management practices under future pest pressure. Agric Syst 144:65-76

Lobell DB, Schlenker W, Costa-Roberts J (2011) Climate trends and global crop production since 1980. Science (May). doi:10.1126/ science. 1204531

Long P, Huang H, Liao X, Fu Z, Zheng H, Chen A, Chen C (2013) Mechanism and capacities of reducing ecological cost through rice-duck cultivation. J Sci Food Agric 93(12):2881-2891
Long TB, Blok V, Coninx I (2016) Barriers to the adoption and diffusion of technological innovations for climate-smart agriculture in Europe: evidence from the Netherlands, France, Switzerland and Italy. J Clean Prod 112:9-21

Lotter DW (2003) Organic agriculture. J Sustain Agric 21(4):59-128

Lowder SK, Skoet J, Raney T (2016) The number, size, and distribution of farms, smallholder farms, and family farms worldwide. World Dev 87:16-29

Luedeling E, Kindt R, Huth NI, Koenig K (2014) Agroforestry systems in a changing climate challenges in projecting future performance. Curr Opin Environ Sustain 6:1-7

Lundgren B (1982) Introduction [Editorial]. Agrofor Syst 1:3-6

Lung AJ, Lin CM, Kim JM, Marshall MR, Nordstedt R, Thompson NP, Wei CI (2001) Destruction of Escherichia coli O157:H7 and Salmonella enteritidis in cow manure composting. J Food Protect 64:1309-1314

Macchi M, Oviedo G, Gotheil S, Cross K, Boedhihartono A, Wolfangel C, Howell M (2008) Indigenous and traditional peoples and climate change. Indigenous and traditional peoples and climate change, IUCN Issues Paper. http://cmsdata.iucn.org/ downloads (Online)

Mäder P, Fliessbach A, Dubois D, Gunst L, Fried P, Niggli U (2002) Soil fertility and biodiversity in organic farming. Science 296 (5573):1694-1697

Magdoff F, Weil R (2004) Soil organic matter management strategies. In: Magdoff F, Weil R (eds) Soil organic matter in sustainable agriculture. CRC Press, Boca Raton

Maikhuri RK, Rao KS, Saxena KG (1996) Traditional crop diversity for sustainable development of Central Himalayan agroecosystems. Int J Sustain Dev World Ecol 3(3):8-31

Mandryk M, Reidsma P, van Ittersum MK (2017) Crop and farm level adaptation under future climate challenges: an exploratory study considering multiple objectives for Flevoland, the Netherlands. Agric Syst 152:154-164

Manna MC, Ghosh PK, Acharya CL (2003) Sustainable crop production through management of soil organic carbon in semiarid and tropical India. J Sustain Agric 21(3):85-114

Mao LL, Zhang LZ, Zhang SP, Evers JB, van der Werf W, Wang JJ, Spiertz H (2015) Resource use efficiency, ecological intensification and sustainability of intercropping systems. J Integr Agric 14(8):1542-1550

Matarira CH, Kamukondiwa W, Mwamuka FC, Makadho JM, Unganai LS (1996) Vulnerability and adaptation assessments in Zimbabwe. In: Lenhart S, Huq S, Mata LJ, Nemesova I, Toure S, Smith JB (eds) Vulnerability and adaptation to climate change: a synthesis of results from the U.S. country studies. U.S. Country Studies Program, Washington, pp 129-140

Matocha J, Schroth G, Hills T, Hole D (2012) Integrating climate change adaptation and mitigation through agroforestry and ecosystem conservation. In: Nair PKR, Garrity D (eds) Agroforestry-the future of global land use. Springer, Netherlands, pp 105-126

Matson PA, Parton WJ, Power AG, Swift MJ (1997) Agricultural intensification and ecosystem properties. Science 277:504-509

Maurya IB, Arvindakshan K, Sharma SK, Jalwania R (2007) Status of indigenous vegetables in Southern Part of Rajasthan. In: Chadha MI, Kuo G, Gowda CLL (eds) Proceedings of the 1st international conference on indigenous vegetables and legumesprospectus for fighting poverty, Hunger and Malnutrition. International Society for Horticultural Sciences (ISHS), Korbeek-Lo, pp 193-196

Mbow C, Van Noordwijk M, Luedeling E, Neufeldt H, Minang PA, Kowero G (2014) Agroforestry solutions to address food security and climate change challenges in Africa. Curr Opin Environ Sustain 6:61-67

McLean KG (2010) Advance guard: climate change impacts, adaptation, mitigation and indigenous peoples - a compendium 
of case studies. United Nations University-Traditional Knowledge Initiative, Darwin. http://www.unutki.org/news.php

McMichael AJ, Powles JW, Butler CD, Uauy R (2007) Food, livestock production, energy, climate change, and health. Lancet 370(9594):1253-1263

McNeely J, Schroth G (2006) Agroforestry and biodiversity conservation-traditional practices, present dynamics, and lessons for the future. Biodivers Conserv 15:549-554

Mehta CM, Uma P, Franke-Whittle IH, Sharma AK (2014) Compost: its role, mechanism and impact on reducing soil-borne plant diseases. Waste Manage 34:607-622

Meijer SS, Catacutan D, Ajayi OC, Sileshi GW, Nieuwenhuis M (2015) The role of knowledge, attitudes and perceptions in the uptake of agricultural and agroforestry innovations among smallholder farmers in sub-Saharan Africa. Int J Agric Sustain 13(1):40-54

Menapace L, Colson G, Raffaelli R (2015) Climate change beliefs and perceptions of agricultural risks: an application of the exchangeability method. Glob Environ Change 35:70-81. doi:10.1016/j.gloenvcha.2015.07.005

Mendelsohn R (1998) Climate-change damages. In: Nordaus WD (ed) Economics and policy issues in climate change. Resources for the Future, Washington, D.C.

Mendham DS, Kumaraswamy S, Balasundaran M, Sankaran KV, Corbeels M, Grove TS, Rance SJ (2004) Legume cover cropping effects on early growth and soil nitrogen supply in eucalypt plantations in south-western India. Biol Fertil Soils 39(5):375-382

Mishra A, Mohanty RK (2004) Productivity enhancement through rice-fish farming using a two-stage rainwater conservation technique. Agric Water Manag 67(2):119-131

Misra RV, Roy RN, Hiraoka H (2003) On-farm composting methods. UN-FAO, Rome

Misra S, Dhyani D, Maikhuri RK (2008) Sequestering carbon through indigenous agriculture practices. Leisa India 10(4):21-22

Mohanty RK, Verma HN, Brahmanand PS (2004) Performance evaluation of rice-fish integration system in rainfed medium land ecosystem. Aquaculture 230(1):125-135

Mohanty S, Swain CK, Sethi SK, Dalai PC, Bhattachrayya P, Kumar A, Lal B (2017) Crop establishment and nitrogen management affect greenhouse gas emission and biological activity in tropical rice production. Ecol Eng 104:80-98

Molua EL (2006) Climate trends in Cameroon: implications for agricultural management. Clim Res 30:255-262

Moniruzzaman S (2015) Crop choice as climate change adaptation: evidence from Bangladesh. Ecol Econ 118:90-98

Montgomery SC, Martin RJ, Guppy C, Wright GC, Flavel RJ, Phan S, Tighe MK (2016) Crop choice and planting time for upland crops in Northwest Cambodia. Field Crops Res 198:290-302

Morton JF (2007) The impact of climate change on smallholder and subsistence agriculture. Proc Natl Acad Sci 104:19680-19685

Motsa NM, Modi AT, Mabhaudhi T (2015) Sweet potato (Ipomoea batatas L.) as a drought tolerant and food security crop. S Afr J Sci 111(11-12):1-8

Mushagalusa GN, Ledent JF, Draye X (2008) Shoot and root competition in potato/maize intercropping: effects on growth and yield. Environ Exp Bot 64:180-188

Mutuo PK, Cadisch G, Albrecht A, Palm CA, Verchot L (2005) Potential of agroforestry for carbon sequestration and mitigation of greenhouse gas emissions from soils in the tropics. Nutr Cycl Agroecosyst 71(1):43-54

Mwongera C, Shikuku KM, Twyman J, Läderach P, Ampaire E, Van Asten P, Twomlowd S, Winowiecki LA (2017) Climate smart agriculture rapid appraisal (CSA-RA): a tool for prioritizing context-specific climate smart agriculture technologies. Agric Syst 151:192-203
Nair PKR (1993) An Introduction to agroforestry. Kluwer Academic Publishers, Dordrecht, p 499

Nair PR, Nair VD, Kumar BM, Haile SG (2009) Soil carbon sequestration in tropical agroforestry systems: a feasibility appraisal. Environ Sci Policy 12(8):1099-1111

Nasiru A, Ismail N, Ibrahim MH (2013) Vermicomposting: tool for sustainable ruminant manure management. $\mathrm{J}$ Waste Manage. doi: $10.1155 / 2013 / 732759$

Nautiyal S, Kaechele H, Rao KS, Maikhuri RK, Saxena KG (2007) Energy and economic analysis of traditional versus introduced crops cultivation in the mountains of the Indian Himalayas: a case study. Energy 32(12):2321-2335

Naylor R, Steinfeld H, Falcon W, Galloway W, Smil V, Bradford E, Alder J, Mooney H (2005) Losing the links between livestock and land. Science 310:1621-1622

Ndegwa PM, Thompson SA (2001) Integrating composting and vermicomposting in the treatment and bioconversion of biosolids. Biores Technol 76(2):107-112

Neher DA, Weicht TR, Bates ST, Leff JW, Fierer N (2013) Changes in bacterial and fungal communities across compost recipes, preparation methods, and composting times. PLoS ONE 8(11): e79512

Neufeldt H, Jahn M, Campbell BM, Beddington JR, DeClerck F, De Pinto A, Gulledge J, Hellin J, Herrero M, Jarvis A (2013) Beyond climate-smart agriculture-towards safe operating spaces for global food systems. Agric Food Secur 2:12

Nhan DK, Phong LT, Verdegem MJC, Duong LT, Bosma RH, Little DC (2007) Integrated freshwater aquaculture, crop and livestock production in the Mekong delta, Vietnam: determinants and the role of the pond. Agric Syst 94:445-458

Niggli U, Fliessbach A, Hepperly P, Scialabba N (2009) Low greenhouse gas agriculture: mitigation and adaptation potential of sustainable farming systems. FAO, Rome

Nilsson LG (1986) Data of yield and soil analysis in the long-term soil fertility experiments. J R Swed Acad Agric For Supply 18:32-70

Ning C, Qu J, He L, Yang R, Chen Q, Luo S, Cai K (2017) Improvement of yield, pest control and $\mathrm{Si}$ nutrition of rice by rice-water spinach intercropping. Field Crops Res 208:34-43

Nkomwa EC, Joshua MK, Ngongondo C, Monjerezi M, Chipungu F (2014) Assessing indigenous knowledge systems and climate change adaptation strategies in agriculture: a case study of Chagaka Village, Chikhwawa, Southern Malawi. Phys Chem Earth Parts A/B/C 67:164-172

Nordhaus WD (1991) To slow or not to slow: the economics of the greenhouse effect. Econ J 101:920-937

Nowak DJ, Crane DE (2002) Carbon storage and sequestration by urban trees in the USA. Environ Pollut 116(3):381-389

Nyong A, Adesina F, Elasha BO (2007) The value of indigenous knowledge in climate change mitigation and adaptation strategies in the African Sahel. Mitig Adapt Strat Glob Change 12 (5):787-797

Oba G (1997) Pastoralists' traditional drought coping strategies in Northern Kenya. A Report for the Government of the Netherlands and the Government of Kenya, Euroconsult BV, Arnheim and Acacia Consultants Ltd, Nairobi

Oelbermann M, Voroney RP, Gordon AM (2004) Carbon sequestration in tropical and temperate agroforestry systems: a review with examples from Costa Rica and southern Canada. Agr Ecosyst Environ 104(3):359-377

Olayide OE, Tetteh IK, Popoola L (2016) Differential impacts of rainfall and irrigation on agricultural production in Nigeria: Any lessons for climate-smart agriculture? Agric Water Manag 178:30-36

Onwosi CO, Igbokwe VC, Odimba JN, Eke IE, Nwankwoala MO, Iroh IN, Ezeogu LI (2017) Composting technology in waste 
stabilization: on the methods, challenges and future prospects. J Environ Manage 190:140-157

Oudart D, Robin P, Paillat JM, Paul E (2015) Modelling nitrogen and carbon interactions in composting of animal manure in naturally aerated piles. Waste Manag 46:588-598

Palang H, Printsmann A, Gyuro EK, Urbanc M, Skowronek E, Woloszyn W (2006) The forgotten rural landscapes of Central and Eastern Europe. Landsc Ecol 21:347-357

Palm CA, Gachengo CN, Delve RJ, Cadisch G, Giller KE (2001) Organic inputs for soil fertility management in tropical agroecosystems: application of an organic resource database. Agric Ecosyst Environ 83(1):27-42

Pandey DN (2002) Carbon sequestration in agroforestry systems. Clim Policy 2(4):367-377

Parry ML, Carter TR (1989) An assessment of the effects of climatic change on agriculture. Clim Change 15:95-116

Parry ML, Arnell NW, McMichael AJ, Nicholls RJ, Martens P, Kovats RS, Livermore MTJ, Rosenzweig C, Iglesias A, Fischer G (2001) Millions at risk: defining critical climate change threats and targets. Glob Environ Change 11:181-183

Paul C, Weber M, Knoke T (2017) Agroforestry versus farm mosaic systems: comparing land-use efficiency, economic returns and risks under climate change effects. Sci Total Environ 587:22-35

Paustian KA, Andrén O, Janzen HH, Lal R, Smith P, Tian G, Woomer PL (1997) Agricultural soils as a sink to mitigate CO2 emissions. Soil Use Manag 13:230-244

Peacock AD, Mullen MD, Ringelberg DB, Tyler DD, Hedrick DB, Gale PM, White DC (2001) Soil microbial community responses to dairy manure or ammonium nitrate applications. Soil Biol Biochem 33:1011-1019

Pedraza V, Perea F, Saavedra M, Fuentes M, Castilla A, Alcántara C (2015) Winter cover crops as sustainable alternative to soil management system of a traditional durum wheat-sunflower rotation in Southern Spain. Proc Environ Sci 29:95-96

Pelletier N, Audsley E, Brodt S, Garnett T, Henriksson P, Kendall A, Troell M (2011) Energy intensity of agriculture and food systems. Annu Rev Environ Resour 36:223-246

Peoples MB, Baldock JA (2001) Nitrogen dynamics of pastures: nitrogen fixation inputs, the impact of legumes on soil nitrogen fertility, and the contributions of fixed nitrogen to Australian farming systems. Aust J Exp Agric 41(3):327-346

Phungpracha E, Kansuntisukmongkon K, Panya O (2016) Traditional ecological knowledge in Thailand: mechanisms and contributions to food security. Kasetsart Journal of Social Sciences 37(2):82-87

Pinto P, Long MEF, Piñeiro G (2017) Including cover crops during fallow periods for increasing ecosystem services: Is it possible in croplands of Southern South America? Agr Ecosyst Environ 248:48-57

Poeplau C, Don A (2015) Carbon sequestration in agricultural soils via cultivation of cover crops-a meta-analysis. Agric Ecosyst Environ 200:33-41

Porter JR, Xie L, Challinor AJ, Cochrane K, Howden SM, Iqbal MM, Lobell DB, Travasso MI (2014) Food security and food production systems. In: Field CB, Barros VR, Dokken DJ, Mach KJ, Mastrandrea MD, Bilir TE, Chatterjee M, Ebi KL, Estrada YO, Genova RC, Girma B, Kissel ES, Levy AN, MacCracken S, Mastrandrea PR, White LL (eds) Climate change 2014: impacts, adaptation, and vulnerability. Part A: global and sectoral aspects, pp. 485-533. Contribution of Working Group II to the Fifth Assessment Report of the Intergovernmental Panel on Climate Change. Cambridge University Press, Cambridge

Powlson DS (1994) In Long-term experiments in agricultural and ecological sciences. In: Leigh RA, Johnston AE (eds), pp 97115. CAB International. Wallingford

Pretty J (1995) Regenerating agriculture. World Resources Institute, Washington, DC
Proietti P, Calisti R, Gigliotti G, Nasini L, Regni L, Marchini A (2016) Composting optimization: integrating cost analysis with the physical-chemical properties of materials to be composted. J Clean Prod 137:1086-1099

Pulido JS, Bocco G (2003) The traditional farming system of a Mexican indigenous community: the case of Nuevo San Juan Parangaricutiro, Michoaca'n, Mexico. Geoderma 111:249-265

Ramanathan V, Xu Y (2010) The Copenhagen Accord for limiting global warming: criteria, constraints, and available avenues. Proc Natl Acad Sci 107(18):8055-8062

Ranells NN, Wagger MG (1996) Nitrogen release from grass and legume cover crop monocultures and bicultures. Agron J 88 (5):777-882

Ranganathan J, Daniels RJR, Chandran MDS, Ehrlich PR, Daily GC (2008) Sustaining biodiversity in ancient tropical countryside. Proc Natl Acad Sci USA 105:17852-17854

Raphael JP, Calonego JC, Milori DMB, Rosolem CA (2016) Soil organic matter in crop rotations under no-till. Soil Till Res 155:45-53

Rashti MR, Wang W, Moody P, Chen C, Ghadiri H (2015) Fertiliserinduced nitrous oxide emissions from vegetable production in the world and the regulating factors: a review. Atmos Environ 112:225-233

Reganold JP, Andrews PK, Reeve JR, Carpenter- Boggs L, Schadt CW, Alldredge JR, Ross CF, Davies NM, Zhou J, El-Shemy AH (2010) Fruit and soil quality of organic and conventional strawberry agroecosystems. PLOS ONE 5(9):12346. doi:10. 1371/journal.pone. 0012346

Redclift M (1989) The environmental consequences of Latin America's agricultural development: some thoughts on the Brundtland Commission report. World Dev 17:365-377

Reeves DW (1994) Cover crops and rotations. Crops Residue Management, Advances in Soil Science, pp 125-172

Reilly J (1995) Climate change and global agriculture: recent findings and issues. Am J Agric Econ 77:727-733

Robačer M, Canali S, Kristensen HL, Bavec F, Mlakar SG, Jakop M, Bavec M (2016) Cover crops in organic field vegetable production. Sci Hortic 208:104-110

Robson JP, Berkes F (2011) Exploring some of the myths of land use change: can rural to urban migration drive declines in biodiversity? Glob Environ Change 21:844-854

Rochette P, Janzen H (2005) Towards a revised coefficient for estimating $\mathrm{N} 2 \mathrm{O}$ emissions from legumes. Nutr Cycl Agroecosyst 73:171-179

Rockström J, Steffen W, Noone K, Persson Å, Chapin FS, Lambin EF, Nykvist B et al (2009) A safe operating space for humanity. Nature 461(7263):472-475

Rojas-Downing MM, Nejadhashemi AP, Harrigan T, Woznicki SA (2017) Climate change and livestock: impacts, adaptation, and mitigation. Clim Risk Manag 16:145-163

Rosenzweig C, Parry ML (1994) Potential impact of climate change on world food supply. Nature 367(6459):133-138

Saarinen T (1976) Environmental planning: perception and behavior. Houghton Mifflin Comp, Boston

Sainju UM, Lenssen AW, Allen BL, Stevens WB, Jabro JD (2016) Nitrogen balance in response to dryland crop rotations and cultural practices. Agric Ecosyst Environ 233:25-32

Salick J, Byg A (Eds.) (2007) Indigenous Peoples and Climate Change. Tyndall Centre, Oxford, UK. http://www.tyndall.ac.uk/ publications/Indigenouspeoples.pdf (Online)

Salick J, Ross N (2009) Traditional peoples and climate change. Glob Environ Change 19:137-139

Sandor JA, Furbee L (1996) Indigenous knowledge and classification of soils in the Andes of southern Peru. Soil Sci Soc Am J 60:1502-1512 
Sanginga N, Lyasse O, Singh BB (2000) Phosphorus use efficiency and nitrogen balance of cowpea breeding lines in a low $\mathrm{P}$ soil of the derived savanna zone in West Africa. Plant Soil 220(1-2):119

Sardaro R, Girone S, Acciani C, Bozzo F, Petrontino A, Fucilli V (2016) Agro-biodiversity of Mediterranean crops: farmers' preferences in support of a conservation programme for olive landraces. Biol Cons 201:210-219

Sauerborn J, Sprich H, Mercer-Quarshie H (2000) Crop rotation to improve agricultural production in Sub-Saharan Africa. J Agron Crop Sci 184:67-72

Sayer J, Cassman KG (2013) Agricultural innovation to protect the environment. Proc Natl Acad Sci 110:8345-8348

Scalise A, Pappa VA, Gelsomino A, Rees RM (2017) Pea cultivar and wheat residues affect carbon/nitrogen dynamics in pea-triticale intercropping: a microcosms approach. Sci Total Environ 592:436-450

Scarpat D, Simeone M (2013) Euro-Mediterranean integration and competitiveness of the agro-food sector: an empirical analysis in Campania region. New Medit 12(3):56-64

Schiere H, Kater L (2001) Mixed crop-livestock farming: a review of traditional technologies based on literature and field experiences. FAO, Rome

Schipanski ME, Barbercheck M, Douglas MR, Finney DM, Haider K, Kaye JP, White C (2014) A framework for evaluating ecosystem services provided by cover crops in agroecosystems. Agric Syst 125:12-22

Schmidhuber J, Tubiello FN (2007) Global food security under climate change. Proc Natl Acad Sci 104(50):19703-19708

Schoeneberger M, Bentrup G, De Gooijer H, Soolanayakanahally R, Sauer T, Brandle J, Current D (2012) Branching out: agroforestry as a climate change mitigation and adaptation tool for agriculture. J Soil Water Conserv 67(5):128A-136A

Selmi S, Boulinier T (2003) Breeding bird communities in southern Tunisian oases: the importance of traditional agricultural practices for bird diversity in a semi-natural system. Biol Cons 110 (2):285-294

Shava S, O’Donoghue R, Krasny ME, Zazu C (2009) Traditional food crops as a source of community resilience in Zimbabwe. Int J Afr Renaiss Stud 4(1):31-48

Shen Q, Wang Y, Chen W, Shi R (1997) Changes of soil microbial biomass $\mathrm{C}$ and $\mathrm{P}$ during wheat growth after application of fertilizers. Pedosphere 7:225-230

Simons AJ, Leakey RRB (2004) Tree domestication in tropical agroforestry. In: New vistas in agroforestry. Springer, Netherlands, pp 167-181

Singh GS, Ram SC, Kuniyal JC (1997a) Changing traditional land use patterns in the Great Himalayas: a case study of Lahaul Valley. J Environ Syst 25:195-211

Singh GS, Rao KS, Saxena KG (1997b) Energy and economic efficiency of the mountain farming system: a case study in the north-western Himalaya. J Sustain Agric 9(2-3):25-49

Singh BR, Borresen T, Uhlen G, Ekeberg E (1998) Long-term effects of crop rotation, cultivation practices and fertilizers on carbon sequestration in soils in Norway. In: Lal R, Kimble JM, Follett RF, Stewart BA (eds) Management of carbon sequestration in soil. CRC Press, Boca Raton, pp 195-208

Singh BB, Ajeigbe HA, Tarawali SA, Fernandez-Rivera S, Abubakar $M$ (2003) Improving the production and utilization of cowpea as food and fodder. Field Crops Res 84(1):169-177

Smit B, Burton I, Klein RJT, Street R (1999) The science of adaptation: a framework for assessment. Miti Adapt Strat Global Change 4:199-213

Smith JB (1996) Using a decision matrix to assess climate change adaptation. In: Smith JB, Bhatti N, Menzhulin G, Benioff R, Budyko MI, Campos M, Jallow B, Rijsberman F (eds) Adapting to climate change: an international perspective. Springer, New York, pp 68-79

Smith JB, Lenhart SS (1996) Climate change adaptation policy options. Clim Res 6:193-201

Smith P, Powlson DS, Glendining MJ, Smith JU (1997) Potential for carbon sequestration in European soils: preliminary estimates for five scenarios using results from long-term experiments. Glob Change Biol 3:67-79

Solomon S (2007) Climate change 2007-the physical science basis: working group I contribution to the fourth assessment report of the IPCC, vol 4. Cambridge University Press, Cambridge

Song X, Ye C (2017) Climate change adaptation pathways for residential buildings in Southern China. Energy Proc 105:3062-3067

Soobhany N, Mohee R, Garg VK (2017) Inactivation of bacterial pathogenic load in compost against vermicompost of organic solid waste aiming to achieve sanitation goals: a review. Waste Manag 64:51-62

Srivastava P, Singh R, Tripathi S, Raghubanshi AS (2016) An urgent need for sustainable thinking in agriculture: an Indian scenario. Ecol Ind 67:611-622

Steele MK, Coale FJ, Hill RL (2012) Winter annual cover crop impacts on no-till soil physical properties and organic matter. Soil Sci Soc Am J 76:2164-2173

Steffen W, Crutzen PJ, McNeill JR (2007) The Anthropocene: are humans now overwhelming the great forces of Nature? Ambio 36:614-621

Stifel LD (1989) Transforming traditional agriculture. In: International Institute of Tropical Agriculture Annual Reports, 1988/89. Ibadan, Nigeria, pp. 6-11

Stocker TF, Qin D, Plattner GK, Tignor M, Allen SK, Boschung J, Midgley PM (2013) Climate change 2013: the physical science basis. Intergovernmental Panel on Climate Change, Working Group I Contribution to the IPCC Fifth Assessment Report (AR5). Cambridge University Press, New York

Sun HY, Deng SP, Raun WR (2004) Bacterial community structure and diversity in a century-old manure-treated agroecosystem. Appl Environ Microbiol 70:5868-5874

Syakila A, Kroeze C (2011) The global nitrous oxide budget revisited. Greenh Gas Meas Manag 1:17-26

Szott LT, Fernandes ECM, Sanchez PA (1991) Soil-plant interactions in agroforestry systems. In: Jarvis PG (ed) Agroforestry: principles and practices. Elsevier, Amsterdam, pp 127-152

Tai AP, Martin MV, Heald CL (2014) Threat to future global food security from climate change and ozone air pollution. Nat Clim Change 4(9):817-821

Takeuchi K (2010) Rebuilding the relationship between people and nature: the Satoyama initiative. Ecol Res 25:891-897

Tebaldi C, Hayhoe K, Arblaster J, Meehl G (2006) Going to the extremes. Clim Change 79(3-4):185-211. doi:10.1007/s10584006-9051-4

Tellez-Rio A, Vallejo A, García-Marco S, Martin-Lammerding D, Tenorio JL, Rees RM, Guardia G (2017) Conservation agriculture practices reduce the global warming potential of rainfed low $\mathrm{N}$ input semi-arid agriculture. Eur J Agron 84:95-104

Tesfahunegn GB, Mekonen K, Tekle A (2016) Farmers' perception on causes, indicators and determinants of climate change in northern Ethiopia: implication for developing adaptation strategies. Appl Geogr 73:1-12

Tester CF (1990) Organic amendment effects on physical and chemical properties of a sandy soil. Soil Sci Soc Am J 65:12841292

Theisen G, Silva JJC, Silva JS, Andres A, Anten NPR, Bastiaans L (2017) The birth of a new cropping system: towards sustainability in the sub-tropical lowland agriculture. Field Crops Research 212:82-94 
Thorup-Kristensen K, Magid J, Stoumann Jensen L (2003) Catch crops and green manure as biological tools in nitrogen management in temperate zones. Adv Agron 79:227-302

Tilman D (1998) The greening of the green revolution. Nature 396 (6708):211-212

Tingem M, Rivington M (2009) Adaptation for crop agriculture to climate change in Cameroon: turning on the heat. Mitig Adapt Strat Glob Change 14(2):153-168

Touch V, Martin RJ, Scott JF, Cowie A, Li Liu D (2016) Climate change adaptation options in rainfed upland cropping systems in the wet tropics: a case study of smallholder farms in North-West Cambodia. J Environ Manage 182:238-246

Triberti L, Nastri A, Baldoni G (2016) Long-term effects of crop rotation, manure and mineral fertilisation on carbon sequestration and soil fertility. Eur J Agron 74:47-55

Tripathi A, Singh GS (2013) Perception, anticipation and responses of people to changing climate in the Gangetic Plain of India. Curr Sci 105:1673-1684

Tripathi A, Tripathi DK, Chauhan DK, Kumar N, Singh GS (2016) Paradigms of climate change impacts on some major food sources of the world: a review on current knowledge and future prospects. Agric Ecosyst Environ 216:356-373

Tubiello FN, Fischer G (2007) Reducing climate change impacts on agriculture: global and regional effects of mitigation, 2000 2080. Technol Forecast Soc Change 74(7):1030-1056

Uhlen G, Tveitnes S (1995) Effects of long-term crop rotation, fertilizers, farm manure and straw on soil productivity. Nor J Agric Sci 9:143-161

Van Dijk H (1982) Survey of Dutch soil organic research with regard to humification and degradation rates in arable land. In: Boels DD, Davis B, Johnston AE (eds) Land use seminar on land degradation. Balkema, Rotterdam, pp 133-143

Verchot LV, Van Noordwijk M, Kandji S, Tomich T, Ong C, Albrecht A, Palm C (2007) Climate change: linking adaptation and mitigation through agroforestry. Mitig Adapt Strat Glob Change 12(5):901-918

VijayaVenkataRaman S, Iniyan S, Goic R (2012) A review of climate change, mitigation and adaptation. Renew Sustain Energy Rev 16(1):878-897

von Cossel M, Möhring J, Kiesel A, Lewandowski I (2017) Methane yield performance of amaranth (Amaranthus hypochondriacus L.) and its suitability for legume intercropping in comparison to maize (Zea mays L.). Ind Crops Prod 103:107-121

Wang ZB (1997) Chronicles of agriculture of Yongjia County. Ocean Press, Beijing, p 11, 631 (in Chinese)

Wang Q, Li Y, Alva A (2010) Cropping systems to improve carbon sequestration for mitigation of climate change. J Environ Prot 1 (03):207

Wang ZB, Chen J, Mao SC, Han YC, Chen F, Zhang LF, Li CD (2017) Comparison of greenhouse gas emissions of chemical fertilizer types in China's crop production. J Clean Prod 141:1267-1274

West TO, Post WM (2002) Soil organic carbon sequestration rates by tillage and crop rotation: a global data analysis. Soil Sci Soc Am J 66:1930-1946

Wheaton EE, Maciver DC (1999) A framework and key questions for adapting to climate variability and change. Mitig Adapt Strat Glob Change 4(3):215-225
Wilken GC (1987) Good farmers: traditional agricultural resource management in Mexico and Central America. University of California Press, Berkeley

Willy RW (1983) Intercropping studies with annual crops. In: Nugent J, O'Connor M (eds) Better crops for food, CIBA foundation symposium 97. Pitman, London, p 1983

Wolf J, Allice I, Bell T (2013) Values, climate change, and implications for adaptation: evidence from two communities in Labrador. Can Global Environ Change 23:548-562

Woods BA, Nielsen HØ, Pedersen AB, Kristofersson D (2017) Farmers' perceptions of climate change and their likely responses in Danish agriculture. Land Use Policy 65:109-120

Yadav H, Fatima R, Sharma A, Mathur S (2017) Enhancement of applicability of rock phosphate in alkaline soils by organic compost. Appl Soil Ecol 113:80-85

Yan Y, Wang YC, Feng CC, Wan PHM, Chang KTT (2017) Potential distributional changes of invasive crop pest species associated with global climate change. Appl Geogr 82:83-92

Yang C, Yang L, Yang Y, Ouyang Z (2004) Rice root growth and nutrient uptake as influenced by organic manure in continuously and alternately flooded paddy soils. Agric Water Manag 70 (1):67-81

You XL (2006) Rice-fish culture: a typical model of sustainable traditional agriculture. Agric Archaeol 4:222-224 (in Chinese)

Young A (1997) Agroforestry for soil management, 2nd edn. CAB International, Wallingford, p 320

Zentner RP, Campbell CA, Biederebeck VO, Miller PR, Selles R, Fernandez MR (2001) In search of a suitable cropping system for the semi-arid Canadian Prairies. J Sustain Agric 18(2-3):117136

Zentner RP, Campbell CA, Biederebeck VO, Selles F, Lemke R, Jefferson PG, Gan Y (2004) Longterm assessment of management of an annual legume green manure crop for fallow replacement in the brown soil zone. Can J Plant Sci 83:475-482

Zhang FS, Li L (2003) Using competitive and facilitative interactions in intercropping systems enhances crop productivity and nutrient use efficiency. Plant Soil 248:305-312

Zhang QC, Shamsi IH, Xu DT, Wang GH, Lin XY, Jilani G, Hussain N, Chaudhry AN (2012) Chemical fertilizer and organic manure inputs in soil exhibit a vice versa pattern of microbial community structure. Appl Soil Ecol 57:1-8

Zhang Y, Min Q, Li H, He L, Zhang C, Yang L (2017a) A conservation approach of globally important agricultural heritage systems (GIAHS): improving traditional agricultural patterns and promoting scale-production. Sustainability 9(2):295

Zhang Y, Min Q, Zhang C, He L, Zhang S, Yang L, Xiong Y (2017b) Traditional culture as an important power for maintaining agricultural landscapes in cultural heritage sites: a case study of the Hani terraces. J Cult Herit 25:170-179

Zheng X, Han S, Huang Y, Wang Y, Wang M (2004) Re-quantifying the emission factors based on field measurements and estimating the direct $\mathrm{N}_{2} \mathrm{O}$ emission from Chinese croplands. Global Biogeochem Cycles 18:GB2018

Zomer RJ, Neufeldt H, Xu J, Ahrends A, Bossio D, Trabucco A, van Noordwijk M, Wang M (2016) Global tree cover and biomass carbon on agricultural land: the contribution of agroforestry to global and national carbon budgets. Sci Rep 6:29987. doi:10. 1038/srep29987 